San Jose State University

SJSU ScholarWorks

Master's Theses

Master's Theses and Graduate Research

Fall 2014

\title{
Effects of Depth, Site, and Season on Phenotypic Variation of the Geniculate Coralline, Calliarthron Tuberculosum around the Monterey Peninsula, California
}

Jasmine Elena Ruvalcaba

San Jose State University

Follow this and additional works at: https://scholarworks.sjsu.edu/etd_theses

\section{Recommended Citation}

Ruvalcaba, Jasmine Elena, "Effects of Depth, Site, and Season on Phenotypic Variation of the Geniculate Coralline, Calliarthron Tuberculosum around the Monterey Peninsula, California" (2014). Master's Theses. 4514.

DOI: https://doi.org/10.31979/etd.2zpw-w9yv

https://scholarworks.sjsu.edu/etd_theses/4514

This Thesis is brought to you for free and open access by the Master's Theses and Graduate Research at SJSU ScholarWorks. It has been accepted for inclusion in Master's Theses by an authorized administrator of SJSU ScholarWorks. For more information, please contact scholarworks@sjsu.edu. 


\title{
EFFECTS OF DEPTH, SITE, AND SEASON ON PHENOTYPIC VARIATION OF THE GENICULATE CORALLINE, CALLIARTHRON TUBERCULOSUM AROUND THE MONTEREY PENINSULA, CALIFORNIA
}

\author{
A Thesis \\ Presented to \\ The Faculty of Moss Landing Laboratories \\ San José State University \\ In Partial Fulfillment \\ of the Requirements for the Degree \\ Master of Marine Science
}

by

Jasmine E. Ruvalcaba

December 2014 
(C) 2014

Jasmine E. Ruvalcaba

ALL RIGHTS RESERVED 
The Designated Thesis Committee Approves The Thesis Titled

EFFECTS OF DEPTH, SITE, AND SEASON ON PHENOTYPIC VARIATION OF THE GENICULATE CORALLINE, CALLIARTHRON TUBERCULOSUM AROUND THE MONTEREY PENINSULA, CALIFORNIA

by

Jasmine E. Ruvalcaba

APPROVED FOR THE FACULTY OF MOSS LANDING MARINE LABORATORIES

SAN JOSÉ STATE UNIVERSITY

December 2014

Dr. Michael H. Graham Moss Landing Marine Laboratories

Dr. Diana Steller Moss Landing Marine Laboratories

Dr. Nicholas Welschmeyer Moss Landing Marine Laboratories 


\title{
ABSTRACT \\ EFFECTS OF DEPTH, SITE, AND SEASON ON PHENOTYPIC VARIATION OF THE GENICULATE CORALLINE, CALLIARTHRON TUBERCULOSUM AROUND THE MONTEREY PENINSULA, CALIFORNIA
}

\author{
by Jasmine E. Ruvalcaba
}

Coralline algae are ubiquitous in near-shore marine environments. In particular, geniculate corallines occur in intertidal and subtidal habitats with abundances typically higher at shallow depths. Due to the high abundance of Calliarthron tuberculosum in Monterey kelp beds, this species was chosen to study effects of depth, site, and season on morphology and physiology.

To further understand this pattern, populations from 3 and $10 \mathrm{~m}$ depth were sampled at two sites to examine morphometric variables including total length, total width, and number of branch tips as well as, physiological variables including respiration, photosynthetic, and calcification rates. Growth rates were also quantified spatially and temporally. The number of branch tips found on shallow individuals was double that of the individuals found at deeper depths while there were no apparent differences in total length and total width with depth. Physiological variables differed but generally were higher in shallow individuals and greater during winter months. There was a depth effect found for growth with shallow individuals generally growing faster than deep individuals. The density of branch tips may facilitate coralline dominance at shallower depths and have implications on the ecology of these near-shore environments. 


\section{ACKNOWLEDGEMENTS}

I would like to thank my thesis committee. Mike Graham for his scientific

knowledge and statistical help, Diana Steller for always making me think again, and Nick Welschmeyer, I had a great time taking Physiology of Marine Algae class.

To all of my field help, without you, I couldn't have done this. Especially Mike Fox and Arley Muth, we had such great time together. To Scott Gabara for photographing my work underwater. To Nora Grant for diving in a pinch. To the BEERPIGS past and present, it is a special group we have. To MLML students for the gracious camaraderie that is grad school. To the MLML small boats program for having such great resources available to students. Kenneth Coale for science and life based conversation. Joan Parker, Michelle O'Keefe, and the library staff for all of their help. James, Billy, Ralph, and Kris for troubleshooting knowledge on the fly. And lastly, my parents Joyce Ruvalcaba and Norm Reynolds, and Stephen Martenuk for daily support throughout this graduate journey, whom have always supported me in all of my endeavors and are truly my backbone. 


\section{Table of Contents}

List of Figures................................................ vii

List of Tables................................................... viii

Introduction....................................................1

Research Question and Objectives..................................6

Methods.........................................................

Results..........................................................13

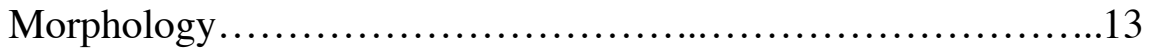

Growth........................................................ 18

Transplant Experiments.....................................22

Pigmentation............................................27

Physiological Parameters....................................31

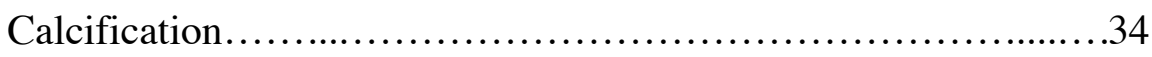

Discussion....................................................... 37

References......................................................44 


\section{$\underline{\text { List of Figures }}$}

Figure 1. Representative $C$. tuberculosum fronds from OTPT (A) shallow and (B) deep exhibiting differences in number of tips.....................................

Figure 2. Mean \pm SE morphological variables of $C$. tuberculosum (A) biomass $\left(\mathrm{kg} \cdot \mathrm{m}^{-2}\right),(\mathrm{B})$ number of branch tips, (C) frond weight (g), and (D) length and width $(\mathrm{cm})$ measured from shallow (3m; black bars) and deep (10m; hashed bars) from Otter Point (OTPT) and Stillwater Cove (SWC).................................16

Figure 3. Average growth rates $\pm \mathrm{SE}$ of $C$. tuberculosum (length; $\mathrm{mm} \cdot \mathrm{month}^{-1}$ and area; $\mathrm{mm}^{2} \cdot \mathrm{month}^{-1}$ ) for (A) Otter Point (OTPT) and (B) Stillwater Cove (SWC)...22

Figure 4. Monthly growth rates from transplant experiments (average \pm SE) for (A)

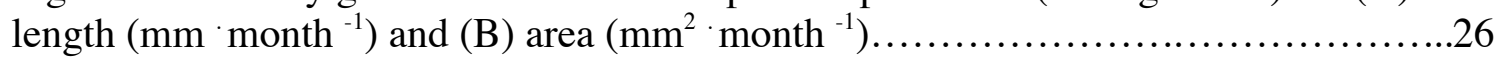

Figure 5. P-I curves for (A) Summer (August) and (B) Winter (March)...................31

Figure 6. August 2012 and March 2013 calcification rates

$\left(\mu \mathrm{mol} \mathrm{CaCO}_{3} \cdot \mathrm{gDW}^{-1} \cdot \mathrm{h}^{-1}\right)$ at $200 \mu \mathrm{mol}$ photons $\cdot \mathrm{m}^{-2} \cdot \mathrm{s}^{-1}$ for shallow and deep individuals at Otter Point (OTPT) and Stillwater Cove (SWC). 


\section{List of Tables}

Table 1. Three-way analysis of variance for (A) coralline mat biomass $\left(\mathrm{kg} \cdot \mathrm{m}^{-2}\right)$, (B) number of tips (per frond), (C) frond weight (g), (D) frond length (cm), and (E) ]frond width $(\mathrm{cm})$ for sites (OTPT and SWC) and depth $(3 \mathrm{~m}$ and $10 \mathrm{~m}) \ldots \ldots \ldots \ldots \ldots \ldots$

Table 2. Two-way analysis of variance of intergenicula (A) width and (B) length for C. tuberculosum for site (OTPT and SWC) and Depth (3m and 10m)....

Table 3. Monthly growth rates (average $\pm \mathrm{SE}$ ) for $C$. tuberculosum in length $\left(\mathrm{mm} \cdot \mathrm{month}^{-1}\right)$ and area $\left(\mathrm{mm}^{2} \cdot\right.$ month $\left.^{-1}\right)$ for season (summer and winter) at Otter Point (OTPT) and Stillwater Cove (SWC).

Table 4. Three-way analysis of variance on $C$. tuberculosum with season, site, and depth for growth measured as (A) length ( $\mathrm{mm}^{\prime}$ month $\left.^{-1}\right)$ and (B) area $\left(\mathrm{mm}^{2} \cdot\right.$ month $\left.^{-1}\right)$.

Table 5. Three-way analysis of variance results for C.tuberculosum transplant experiments with transplant, depth, and treatment for (A) length

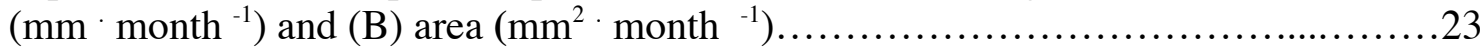

Table 6. Monthly growth rates for $C$. tuberculosum during (A) transplant 1 at Otter Point, (B) transplant 2 at Otter Point, and (C) Transplant 3 at Stillwater Cove....

Table 7. Pigment concentrations (average $\mu \mathrm{g} \cdot \mathrm{gDW}^{-1} \pm \mathrm{SE}, \mathrm{Chl} a$; chlorophyll a, PE; phycoerythrin, PC; phycocyanin, and APC; allophycocyanin) for season (summer and winter), site (OTPT; Otter Point and SWC; Stillwater Cove), and depth (shallow and deep)

Table 8. Multi-factor analysis of variance with season, site, and depth for pigment concentrations (Chl $a$; chlorophyll $a, \mathrm{PE}$; phycoerythrin, PC; phycocyanin, and APC; allophycocyanin) for season (summer and winter), site (OTPT; Otter Point and SWC; Stillwater Cove), and depth (shallow and deep).

Table 9. Pigment ratios (PE; phycoerythrin, PC; phycocyanin, APC; allophycocyanin, and $\mathrm{Chl} a$; chlorophyll $a$ ) for season (summer and winter), site (OTPT; Otter Point and SWC; Stillwater Cove), and depth (shallow and deep)......

Table 10. Multi-factor analysis of variance of season, site, and depth for pigment ratios (PE:PC; phycoerthyrin:phycocyanin, PC:APC; phycocyanin:allophycocyanin, and PE:Chl $a$; phycoerythrin:chlorophyll $a$ ) 
Table 11. Average $\pm \mathrm{SE}$ for respiration rates, maximum photosynthetic rates $\left(\mathrm{P}_{\max }\right)$, alpha $(\alpha)$ for season (summer and winter), site (OTPT; Otter Point and SWC;

Stillwater Cove), and depth (shallow and deep)......................................

Table 12. Calcification rates (average $\pm \mathrm{SE}$ ) for season (summer and winter), site (OTPT; Otter Point and SWC; Stillwater Cove), and depth (shallow and deep)...........35

Table 13. Analysis of variance with season, site, and depth for calcification rate........36 


\section{Introduction}

Morphological variation in marine macroalgae is affected by environmental factors including light, temperature, salinity, water motion, and availability of nutrients (Lobban and Harrison 1997), as well as potential interactions amongst these factors. Such abiotic factors vary between intertidal and subtidal environments at the same site, latitudinally, and across broad temporal scales (e.g., days to decades). Morphological form and physiological function are generally correlated (Littler 1980, Arnold and Murray 1980, Hay 1986, Johansson and Snoeijs 2002). For example, filamentous and sheet-like algal species typically have greater photosynthetic rates per gram of tissue compared to coarsely branched, thick and leathery, and calcified species (Littler and Littler 1980). The latter species exibit higher environmental resistance (hardiness), with a higher ratio of structural components to photosynthetic components, resulting in lower mass-specific photosynthesis.

Because seaweeds are autotrophs, light is a major factor influencing algal morphology and physiology and variable light conditions can directly influence their fitness (Kirk 2011). The light environment within which subtidal seaweeds live is modified by three primary factors: water depth (excluding competitive shading), water transparency, and temporal variability in surface irradiance (Kirk 2011). It is well established that light quantity decreases with depth as light is absorbed and scattered by particles in the water (Jerlov 1976), with generally negative effects on algal physiology (Johannson and Snoeijs 2002, Colombo-Pallotta et al. 2006, Edwards and Kim 2010). The subtidal light environment varies seasonally due to changes in day length, solar 
incidence, turbidity, run-off, plankton blooms, and overlying vegetation, as well as on daily scales due to cloud cover (Lobban and Harrison 1997).

Seaweeds can respond to changes in light quantity and quality by varying morphologically. In Asparagopsis armata, branch size and shape (i.e., fewer branches with branch elongation) change under reduced irradiance (Monro and Poore 2005). Shifts in growth between branch elongation and meristem production were due to variation in spectral quality. Halimeda tuna, a calcified green alga, exhibited natural plasticity in morphology relative to depth (light intensity) with deeper thalli growing at 6 $m$ having thinner segments, larger utricles, and thinner cell walls than shallow plants from $0.5 \mathrm{~m}$ (Colombo and Orsenigo 1977). Studies of various Caluerpa spp. have shown morphological responses to reduced illumination (Calvert 1976), resulting in change of symmetry of ramular placement from radial to bilateral in low light. Many studies have also shown changes in physiology with depth related light reduction (Ramus et al. 1976, Silva et al. 1998, Colombo-Pallotta et al. 2006), diurnal changes in irradiance (LopezFigueroa 1992), and seasonal changes in irradiance (Luder et al. 2001, Fairhead et al. 2004).

Hydrodynamic regimes vary with site and depth and have profound effects on both algal and invertebrate morphology and physiology (Wheeler 1988, Baeck 1993, Hurd et al. 1996, Hurd 2000, Wernberg et al. 2005, Koehl et al. 2008). Coral branching morphology can vary with depth, where branch spacing increases along a depth gradient (Sebens et al. 1997, Helmuth et al. 1997). 
Algal species respond morphologically and physiologically to both light and water motion (Wing et al. 2007, Yniguez et al. 2010). Steneck and Adey (1976) found that growth rates and branching in Lithophyllum congestum transplanted to areas of high water motion (shallow depths) increased relative to deeper transplants. Steller and Foster (1995) suggested that the morphology of free living, branched crustose coralline algae (rhodoliths) was influenced by a suite of environmental factors (e.g., light, water motion, and sedimentation). Morphological variability has also been shown in corallites, where plasticity in coral species responds to multiple environmental factors (Foster 1979, Bruno and Edmunds 1997). In Ascophyllum nodosum, phenotypic acclimation, in addition to genetic variation in thallus morphology, enables this species to occupy a wide zone in the intertidal and tolerate a variety of environmental factors (Stengel and Dring 1997).

Light and water motion vary with depth creating a range of algal habitats and zones in nearshore environments. Kelp forests are highly productive habitats that promote biodiversity among many trophic levels in nearshore environments (Foster 1975a, Reed and Schiel 1985, Steneck et al. 2002, Estes et al. 2004, Graham 2004). The distribution of algal species within a kelp forest is a result of interactions among various abiotic (e.g., light and temperature) and biotic (e.g., competition and grazing) factors (Foster 1975b, Reed and Schiel 1985, Schiel and Foster 1986). Dayton et al. (1984) categorized kelp forest vegetative layers in California by morphological adaptations: 1) floating surface canopies like, Macrocystis pyrifera and Nereocystis luetkeana,2) an understory of stipitate, erect kelp species such as Pterygophora califonica, Eisenia arborea, and/or Laminaria setchellii, 3) a prostrate canopy (Laminaria farlowii, 
Dictyoneurum californicum), 4) a turf of articulated coralline algae (e.g., Calliarthron spp.) and other foliose red algae, and 5) a basal encrusting coralline algal layer (e.g., Lithophyllum spp.). In addition to dealing with variation in the light environment due to abiotic factors, subcanopy species must also respond to competition for light with canopy forming species above them (Reed and Foster 1984, Foster and Schiel 1986).

Seasonal changes in oceanographic conditions can result in spatial and temporal variation in canopy-forming species. In central California, Macrocystis pyrifera canopy cover is variable across the Monterey Peninsula along a wave-exposure gradient (Graham et al. 1997). Canopy cover variability, canopy loss, and periods of low canopy cover are greatest at sites exposed to greater wave action relative to protected sites (Graham 1997). Benthic light irradiances vary with the presence or absence of kelp canopies, as well as beneath canopies of different kelp species, with reductions in irradiances under multiple canopies (Neushul 1971, Reed and Foster 1984, Clark et al. 2004). Seasonally, along the Monterey Peninsula, surface canopy cover of M. pyrifera increases during spring due to higher growth under upwelling conditions. The resulting thick summer canopy is then exposed to subsequent large storm events and swell action during fall and winter months which removes canopy biomass (Harrold et al. 1988, Graham et al. 1997). While large swells may remove entire Macrocystis sporophytes (Ebeling et al. 1985, Graham et al. 1997, Arkema et al. 2009), stands of the understory kelp P. californica may remain and continue as competitors for space and light (i.e. inhibiting recruitment of other species; Dayton and Tegner 1984) influencing the recruitment, survival, and physiological performance of understory algal species (Pearse and Hines 1979, Reed and Foster 1984, 
Watanabe et al. 1992). The high cover of articulated coralline algae and increased wave heigth at shallower depths along the Monterey Peninsula (Cowen et al. 1982, Graham 1997), may inhibit kelp recruitment by drastically reducing light availability, restricting canopies to deeper waters (Graham 1997).

Crustose (non-geniculate) and upright (geniculate) coralline algae are abundant from polar regions to the tropics (Johansen 1981, Steneck 1986). Crustose species grow prostrate to the substrate, whereas upright species have individual fronds consisting of intergenicula (for light reception) and genicula (flexible joints allowing fronds to bend and reorient in high water motion). Geniculate corallines are abundant intertidally and subtidally, especially within the understory community in kelp forests around the Monterey Peninsula (Johansen and Austin 1970, Devinny and Kirkwood 1974, Reed and Schiel 1985, Harrold et al. 1988, Clark et al. 2004, Martone 2006). The abundance of geniculate corallines in kelp beds around the Monterey Peninsula decrease with depth and ranges from $\sim 26 \%$ in shallow depths $(4-6 \mathrm{~m}), \sim 16 \%$ in mid depths $(10-14 \mathrm{~m})$, to $\sim 12 \%$ in deep regions (15-20 m) (PISCO unpublished 1999-2003). However, in some shallow sites cover can be much greater. For example, Graham (1997) found the abundance of upright corallines to be $\sim 90 \%$ cover at a wave exposed site $(\sim 2.5 \mathrm{~m})$ along the Monteey Peninsula. Calliarthron spp. are upright corallines that are slow growing and long-lived. Yet they can be early colonizers on bare substratum, resulting in persistent coverage over many years (Johansen and Austin 1970, Foster 1975a, Reed and Schiel 1985, Edwards 1998). Due to the high abundance of this species in Monterey kelp beds and the documented changes in percent cover C. tuberculosum in relation to depth, this species 
was chosen to study depth related phenotypic variation in morphology and physiology at two sites on the Monterey Peninsula.

Algal growth rates can be used to assess productivity (Mann 1973, Vadas 2004). The morphological and physiological response of a species to its environment can differ seasonally and annually. Johansen and Austin (1970) found that shallow water ( 5 m) $C$. tuberculosum individuals were commonly around $8-12 \mathrm{~cm}$ in length, whereas individuals at greater depths (10-11 m) were more elongated growing up to (or more than) $20 \mathrm{~cm}$. Seasonal growth for subtidal C.tuberculosum was slower $(1.3 \mathrm{~mm} / \mathrm{month})$ during summer months (April-September) than winter months (October-March) (2.3 $\mathrm{mm} / \mathrm{month})$. The authors attributed the changes in growth to a metabolic effect in relation to winter conditions, with slightly lower temperatures and the change in quantity of light reaching the benthos due to loss and removal of Macrocystis. Drastic changes in available light between the summer (low light) and winter (high light) months are primarily due to seasonal variability of the kelp canopy (Graham et al. 1997). Furthermore, thicker canopies are generally found in more protected habitats, while thinner canopies are found in higher exposed habitats relative to water motion. Due to the limited data on morphological parameters, growth, and physiological variables in relation to depth at multiple sites, $C$. tuberculosum was chosen as a study species.

To examine factors influencing phenotypic variability of an important kelp forest species this study was conducted to investigate the morphology, growth, and physiology of C.tuberculosum at $3 \mathrm{~m}$ and $10 \mathrm{~m}$ depth at two sites along the Monterey Peninsula. The following questions were addressed: (1) Do variables of frond morphology (frond 
length, width, number of tips, individual weight, and biomass) and intergenicula morphology (intergenicula length and width) of C. tuberculosum change with depth and site? (2) Do C. tuberculosum growth rates (change in apical growth and area) vary with depth, site, and season? (3) Does C. tuberculosum physiology vary with depth, site, and season? These questions will help characterize C. tuberculosum populations at $3 \mathrm{~m}$ and $10 \mathrm{~m}$ at different sites along the Monterey Peninsula.

\section{Methods}

\section{Site Selection}

Two sites along the Monterey Peninsula, central California, were chosen and identified from prior studies (Graham et al. 1997, Clark et al. 2004). Otter Point (OTPT) is located on the east side of the Peninsula and is composed of granitic outcrops and sand channels with primary swell directions of N and NW. Stillwater Cove (SWC) is a more protected location on the west side of the Peninsula, in Carmel Bay, and is comprised of granitic outcrops and sand channels, with primary swell directions of W, SW, and S. Within each site, two depths ( $3 \mathrm{~m}$ and $10 \mathrm{~m}$ ), varying in light and kelp canopy cover, were selected to investigate differences in morphology and physiology of $C$.

tuberculosum. The two sites were used to assess whether morphology and physiology varied with depth and site. 


\section{Morphological variation}

Algal morphology was investigated by haphazardly placing twelve replicate 6-inch PolyVinyl Chloride (PVC) round quadrats $\left(75.2 \mathrm{~cm}^{2}\right)$ at each depth at each site during July 2011. All biomass wihin the quadrat was removed by scraping along the benthos within the quadrat. Total length and width $(\mathrm{cm})$, number of growing branch tips, intergenicular wing expansion, intergenicular wing width, and intergenicula length $(\mathrm{mm})$ were measured from all complete individual fronds within each sample. Biomass (wet weight) was esimated by weighing all $C$. tuberculosum fronds within each quadrat. The fifth intergeniculum from the apex of a random frond from a whole individual was used to measure wing expansion and length from shallow and deep individuals (adapted methods from Gabrielson et al. 2011).

\section{Growth rate}

Seasonal growth rates of $C$. tuberculosum were studied at each depth at OTPT during August-September 2013 and November 2012-May 2013 and at SWC during JulySeptember 2012 and February-June 2013. Individual C. tuberculosum fronds were stained in situ with Calcoflour white (ENG Scientific Calcofluor White Stain \#6726) in order to determine growth rates and variation in morphology relative to depth during summer and winter months. Staining methods were adapted from Martone (2010), where plastic bags $(3.79 \mathrm{~L})$ containing vials of Calcoflour stain solution $(1.5 \mathrm{~mL})$ were placed around six handful-sized bunches of individuals and secured as close to the basal crust as

possible with a cable tie at each depth. Frond bunches were exposed to the stain for three 
days, after which bags were removed and fronds were tagged. After the outplanted period stained individuals were collected by removing the basal holdfast and brought back to the lab for quantification of growth. Calcofluor white is a non-specific fluorochrome that binds to the apical growing tips of C. tuberculosum and is detectable (fluoresces) by photographing branches under UV light. Micrograph pictures were taken under UV light with a Leica dissecting scope with a mounted camera and Basic Spot $\odot$. Growth increments were analyzed in ProPlus@ by measuring growth that occurred after the stain mark to the tip of the intergenicula and reported in $\mathrm{mm}$ month for apical length and $\mathrm{mm}^{2} \cdot$ month for area. Multiple tips of single fronds were measured, averaged to provide growth of a single replicate.

A manipulative experiment was used to examine if growth and morphology of $C$. tuberculosum were affected by transplantation from shallow to deep and vice versa. Due to logisitics three transplant trials were conducted at different times and locations. Individual C. tuberculosum fronds were transplanted between December 8, 2012-March 10, 2013 and November 1,2012-May 31, 2013 at OTPT and January 30,2013-June 17, 2013 at SWC. During each transplant trial individual C. tuberculosum fronds were deployed by installing eyebolts into the granitic outcrops. During each trasplant trial two PVC quadrats were attached to bolts with cable ties at the two depths $(3 \mathrm{~m}$ and $10 \mathrm{~m})$. Before deployment, all fronds were stained with Calcoflour white in order to mark initiation of transplants. Individual fronds were taken from each depth and brought back to the laboratory, where they were stained with Calcofluor in shallow tubs with aeration for three days. Treatments consisted of fronds that (1) originated at $3 \mathrm{~m}$ and were 
transplanted to $10 \mathrm{~m}$ and fronds that originated at $10 \mathrm{~m}$ and were transplanted to $3 \mathrm{~m}$ (transplant treatments: T), (2) fronds that originated at $3 \mathrm{~m}$ and were transplanted to $3 \mathrm{~m}$ and fronds that originated at $10 \mathrm{~m}$ and were transplanted to $10 \mathrm{~m}$, (transplant controls; TC); and (3) individual fronds at each depth stained in situ, (control; C). There were 6-8 replicates of each treatments, resulting in 12 to 16 stained fronds that were individually attached to each quadrat. After the growth period, samples were collected and apical growth and area of stained intergenicula were measured with microscopy as described above.

\section{Physiology}

Individual C. tuberculosum fronds varying in morphology were chosen for steadystate primary production experiments to determine if there were physiological differences between depths within each site, between sites, and between seasons. During August 2012 and March 2013, individual fronds of C.tuberculosum were taken from $3 \mathrm{~m}$ and 10 $\mathrm{m}$ at both Central California sites on a single day to assess physiological variables. Samples were transported in a cooler with aeration from Moss Landing Marine Laboritories (MLML) to Coastal and Marine Institute and Laboratory (CMIL) at San Diego State University and held in a dark cold room $\left(10^{\circ} \mathrm{C}\right)$ until experiments were started. Eighty-four (500 mL) B.O.D. incubation bottles were filled with filtered (Prime $\mathrm{xUp}$ sediment filter) seawater (from MLML) at the same time and held at $10^{\circ} \mathrm{C}$ in the dark for subsequent incubations. For each site and depth, single fronds ( $3 \mathrm{~g})$ were cleaned of epiphytes and epifauna and placed in incubation bottles. Bottles with no 
fronds were used as reference controls. Incubations were held in a waterbath within a cold room $\left(10^{\circ} \mathrm{C}\right.$ for 2.5 hours $)$ under light treatments of $0,15,30,75,100$, and $200 \mu \mathrm{mol}$ photons $\mathrm{m}^{-2} \cdot \mathrm{s}^{-1}$. All light treatments had three replicates and three reference bottles with no material. Carbon assimilation ( $\mu$ mol carbon $\mathrm{kg}^{-1}$ of seawater) was determined by potentiometric titration with a Metrohm 765 Dosimat titrator and Orion 920A pH meter connected to a PC by RS232 communication cable. Samples were measured in a jacketed beaker with recirculating water held at $25^{\circ} \mathrm{C}$, which sat on a Metrohm 728 magnetic stirrer. The RS232 cable relayed the amount of acid titrated and resulting electromotive force (EMF) to titration custom software (Q-basic) to determine total inorganic carbon and total alkalinity. Data were standardized with reference bottles by subtracting total inorganic carbon (TIC) in reference bottels from TIC in sample bottles to account for any carbon activity occuring in the sample water during each incubation. Then data were standardized with dry weight (g) of each sample. Replicates for each irradiance were averaged and plotted in Grapher to obtain physiological parameters: $\mathrm{P}_{\max }$, as maximum photosynthetic rate and $\alpha$, as photosynthetic efficiency with the equation from Webb et al. (1974). To calculate saturation irriadiance $\left(I_{k}\right), x$ was solved for with $\mathrm{P}_{\max }=\alpha(\mathrm{x})+$ respiration. For compensation irradiance $\left(\mathrm{I}_{\mathrm{c}}\right), \mathrm{x}$ was solved for with $0=\alpha$ (x) + respiration. Calcification rates were estimated using the alkalinity anomaly technique (Smith and Key 1975), using the equation, calcification $=((\Delta$ total alkalinity $\bullet$ volume incubated $) /(2 \cdot$ incubation time $)) /$ dry weight 


\section{Pigment anaylsis}

To assess variability in pigment concentrations relative to depth, site, and season for phycoerythrin, phycocyanin, allophycocyanin, and chlorophyll $a$, ten individual fronds from each depth and site were taken during Septemeber 2012 and March 2013. Each frond was pulverized with a ball mill and one gram of tissue was used to extract chlorophyll and phycobilins. Phycobilins were extracted first using $10 \mathrm{~mL}$ of potassium phosphate buffer $(0.1 \mathrm{M}, \mathrm{pH} 6.8)$ for 24 hours at $4^{\circ} \mathrm{C}$ in the dark. The supernatant was drawn off the pellet and $90 \%$ acetone was then used to extract chlorophyll $a$ for 24 hours at $4^{\circ} \mathrm{C}$ in the dark. Chlorophyll was extracted twice from all samples. All samples were vortexed and centrifuged ( $5 \mathrm{~min}$ at 6,000 rpm). The supernatant for phycobilins and chlorophyll $a$ was analyzed on a Jasco V530 spectrophotometer with Spectra Manager. Trichromatic equations were used to calculate chlorophyll (Arnon 1949) and phycobilin (Luder et al. 2001) concentrations.

Statistical Analysis

Two-way ANOVAs were used to examine differences in morphological variables between sites and depths. Additionally, when season was a factor (for growth and physiological variables), a three-way ANOVA was used with Tukey's post-hoc comparisons to identify specific differences. All values are reported as averages with standard errors. 


\section{Results}

\section{Total Biomass}

Biomass was greater at shallow depths relative to deep at both sites (Fig 2A). However, an interaction was found between site and depth on biomass indicating the depth effect was site-specific. OTPT shallow biomass was significantly greater than shallow biomass from SWC (Table 1). At OTPT, total biomass $\left(\mathrm{kg} \cdot \mathrm{m}^{-2}\right)$ was 6-fold greater at $3 \mathrm{~m}$ with roughly $13 \mathrm{~kg}$ of corallines compared to about $2 \mathrm{~kg}$ at $10 \mathrm{~m}$ (Figure 2A). At SWC, biomass $\left(\mathrm{kg} \cdot \mathrm{m}^{-2}\right)$ was significantly greater at $3 \mathrm{~m}$ with an average of $7 \mathrm{~kg}$ compared to $10 \mathrm{~m}$ with an average of $4 \mathrm{~kg}$ (Table $2 \mathrm{~A})$.

\section{Branch Tips}

Photographs of representative $C$. tuberculosum fronds from OTPT shallow and deep exhibiting differences in number of branch tips are shown in Figure 1.

A general depth effect was found between shallow and deep populations where the number of branch tips found on a shallow individual frond was significantly greater than a deep frond (Table 1A, Figure 2B). However, there was no interaction found between site and depth. At OTPT, shallow fronds $(\bar{x}=158 \pm 34, \mathrm{n}=13)$ had significantly greater number of branch tips per frond compared to deep fronds $(\bar{x}=72 \pm 14, \mathrm{n}=15$; Figure 2B). SWC shallow fronds $(\bar{x}=163 \pm 30, \mathrm{n}=15)$ also had significantly greater number of tips than deep fronds $(\bar{x}=58 \pm 7, \mathrm{n}=14$; Figure $2 \mathrm{~B})$. 


\section{Frond weight}

No effects were found between site, depth, or the interaction for frond weight (Table 1C), although frond weight (g) was generally greater in shallow individuals than individuals from the deep at both sites (Figure 2C). Frond weight (wet weight in $\mathrm{g}$ ) in shallow indivuduals $(\bar{x}=9.1 \pm 2.45, \mathrm{n}=29)$ was greater than deep individuals $(\bar{x}=3.6 \pm$ 0.76; Figure 1C) at OTPT. At SWC individuals weighed more than those at OTPT, though insignificant and shallow individuals $(\bar{x}=23.72 \pm 12.24, \mathrm{n}=15)$ were greater than deep individuals $(\bar{x}=3.45 \pm 0.63, \mathrm{n}=14)$; Figure $2 \mathrm{C})$.

\section{Frond Length}

Frond length did not vary with either site or depth for shallow individuals compared to deep individuals (Table 1D). The average total length $(\mathrm{cm})$ of shallow fronds at OTPT $(\bar{x}=11.3 \pm 0.5, \mathrm{n}=29)$ was greater than deep fronds $(\bar{x}=9.2 \pm 0.7, \mathrm{n}=$ 29) but average total length at SWC of shallow fronds $(\bar{x}=11.1 \pm 0.7, \mathrm{n}=15)$ was similar to deep fronds $(\bar{x}=11.1 \pm 0.5, \mathrm{n}=15)$ at SWC (Figure 2D).

\section{Frond Width-}

There was no effect of site or depth on total frond width (Table 1E). Total width $(\mathrm{cm})$ at OTPT in shallow $(\bar{x}=12.2 \pm 1.3 \mathrm{~cm}, \mathrm{n}=13)$ and deep $(\bar{x}=9.8 \pm 1.0 \mathrm{~cm}, \mathrm{n}=29)$ fronds was similar (Figure 2D), as well as, total width of shallow $(\bar{x}=1.3 \pm 1.0, \mathrm{n}=15)$ and deep $(\bar{x}=11.7 \pm 0.7, \mathrm{n}=14$; Figure $2 \mathrm{D})$ fronds at SWC. 


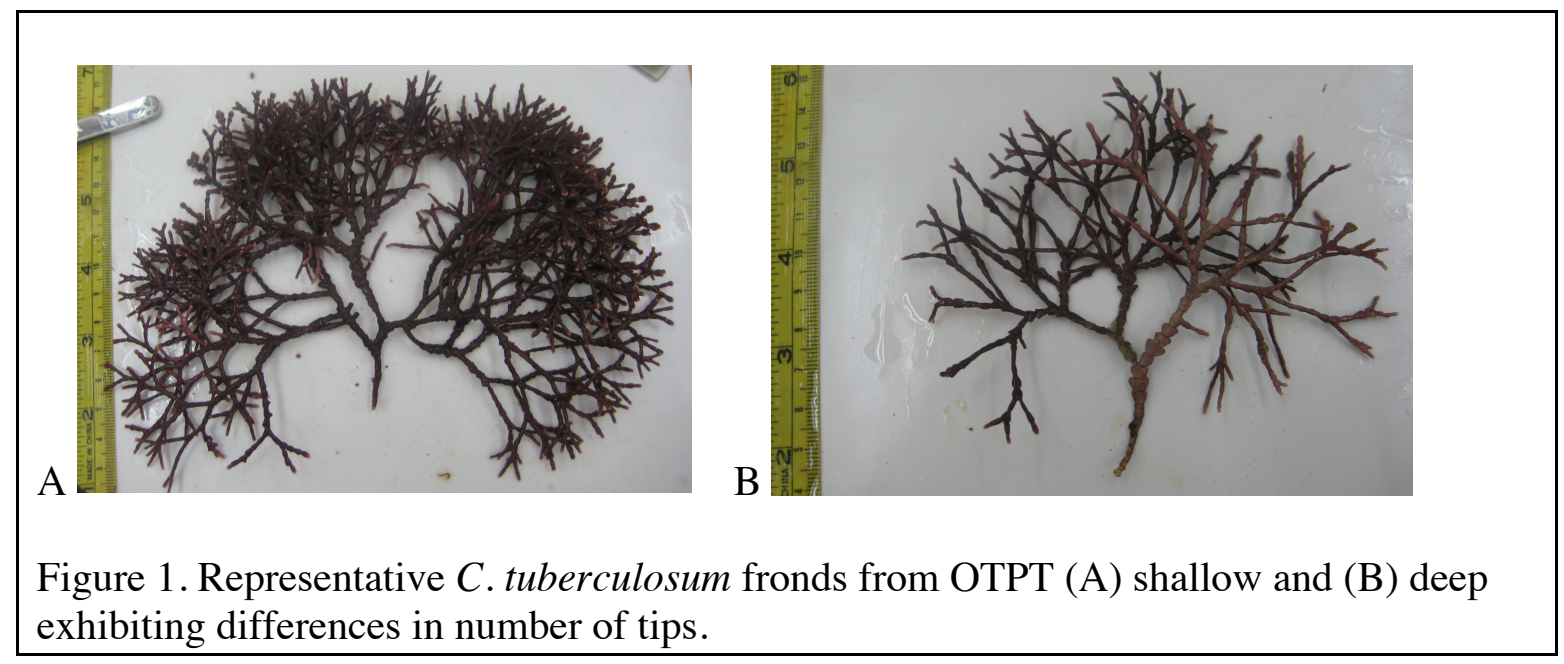

Table 1. Three-way analysis of variance for (A) coralline mat biomass $\left(\mathrm{kg} \bullet \mathrm{m}^{-2}\right),(\mathrm{B})$ number of tips (per frond), (C) frond weight $(\mathrm{g}),(\mathrm{D})$ frond length $(\mathrm{cm})$, and $(\mathrm{E})$ frond width $(\mathrm{cm})$ for sites (OTPT and SWC) and depth (3m and $10 \mathrm{~m})$.

\begin{tabular}{|cccccc}
\hline Dependent Variable & Source & DF & MS & F & P \\
\hline \hline & Site & 1 & 8058.305 & 6.627 & 0.014 \\
(A) Biomass & Depth & 1 & 95386.653 & 78.446 & $<0.001$ \\
& Site ${ }^{*}$ Depth & 1 & 22604.316 & 18.59 & $<0.001$ \\
& Error & 42 & 1215.958 & & \\
\hline & Site & 1 & 339.053 & 0.041 & 0.840 \\
(B) Tips & Depth & 1 & 131821.959 & 15.934 & $<0.001$ \\
& Site * Depth & 1 & 1254.908 & 0.152 & 0.698 \\
& Error & 54 & 8272.776 & & \\
\hline & Site & 1 & 750.659 & 1.093 & 0.301 \\
(C) Frond weight & Depth & 1 & 2400.169 & 3.494 & 0.067 \\
& Site * Depth & 1 & 782.896 & 1.14 & 0.291 \\
& Error & 54 & 687.036 & & \\
\hline & Site & 1 & 10.109 & 1.873 & 0.177 \\
(D) Frond length & Depth & 1 & 15.465 & 2.866 & 0.096 \\
& Site $*$ Depth & 1 & 14.832 & 2.749 & 0.103 \\
& Error & 54 & 5.396 & & \\
\hline & Site & 1 & 3.731 & 0.249 & 0.620 \\
& Depth & 1 & 15.069 & 1.004 & 0.321 \\
& Site * Depth & 1 & 27.045 & 1.803 & 0.185 \\
& Error & 54 & 687.036 & & \\
\hline
\end{tabular}




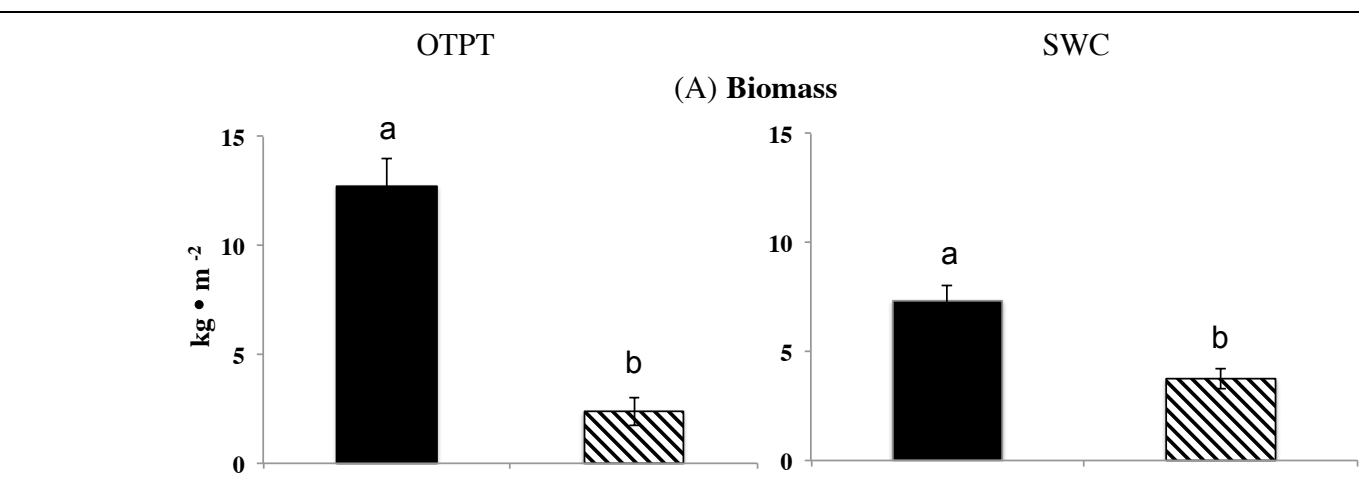

(B) Branch tips
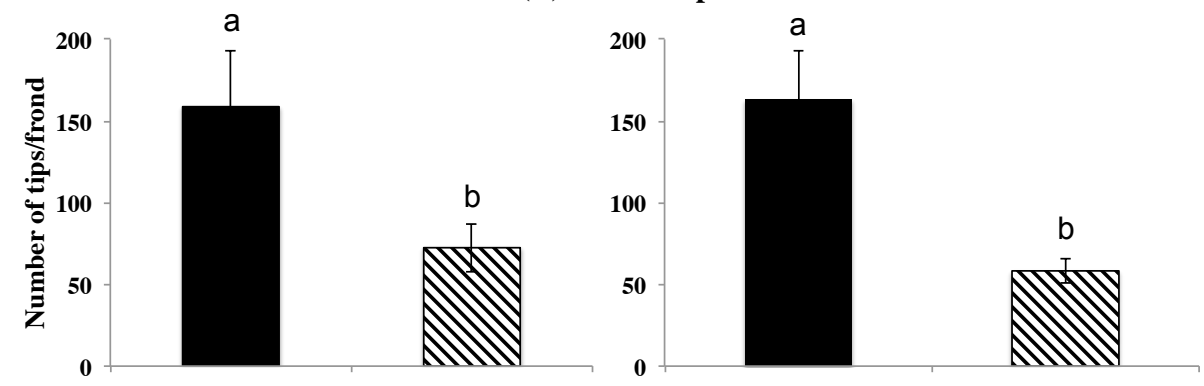

(C) Frond weight
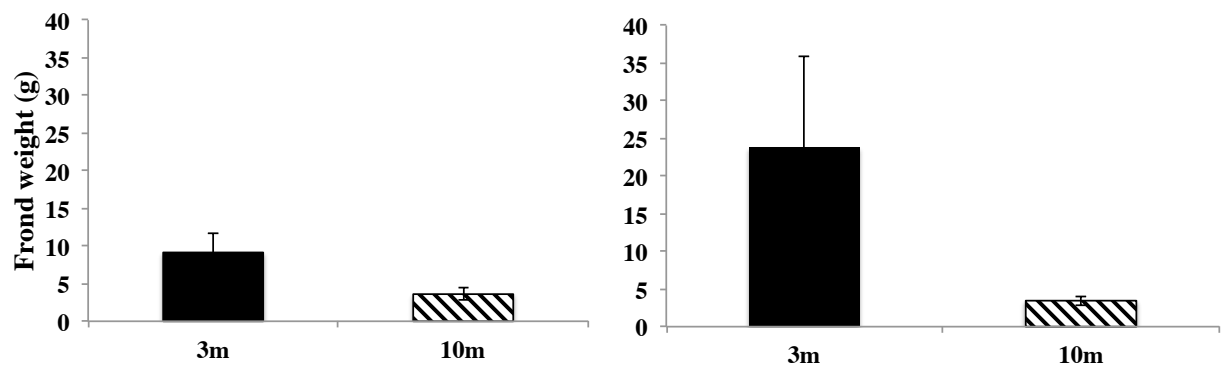

(D) Total frond length and width
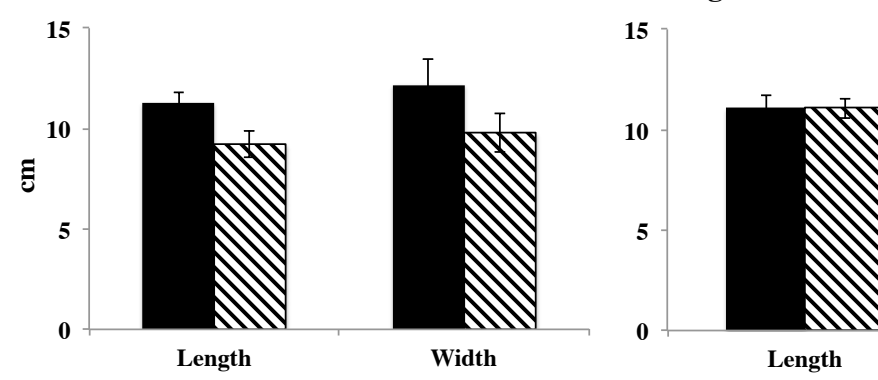

Figure 2. Mean \pm SE morphological variables of $C$.tuberculosum (A) biomass $\left(\mathrm{kg}^{\mathrm{m}} \mathrm{m}^{-2}\right)$, (B) number of branch tips, (C) frond weight (g), and (D) length and width (cm) measured from shallow ( $3 \mathrm{~m}$; black bars) and deep (10m; hashed bars) from Otter Point (OTPT) and Stillwater Cove (SWC). Letters denote significant differences at the 0.05 level for depth. 


\section{Intergenicula Morphology}

\section{Intergenicula Length}

Intergenicula length ranged from 1.44 to $5.13 \mathrm{~mm}$. An interaction effect between site and depth was significant for intergenicula length, but the only ecologically significant difference was found at SWC where longer intergenicula were found in shallow indivduals than shallow indivduals at OTPT. Within site specifically, OTPT deep individuals $(\bar{x}=3.35 \pm 0.32, \mathrm{n}=20)$ have significantly longer intergenicula compared to shallow individuals $(\bar{x}=1.79 \pm 0.25, \mathrm{n}=32)$. At SWC, no differences were found in length of intergenicula between shallow $(\bar{x}=3.13 \pm 0.11, \mathrm{n}=25)$ and deep $(\bar{x}=$ $3.16 \pm 0.18, \mathrm{n}=28$ ) individuals (Table 2).

\section{Intergenicula Width}

Intergenicula width ranged from 0.56 to $6.56 \mathrm{~mm}$ and did not vary by site or depth in this study (Table 2). OTPT shallow intergeniculum width $(\mathrm{mm})(\bar{x}=2.83 \pm$ $0.31, \mathrm{n}=32)$ was similar to deep individuals $(\bar{x}=2.47 \pm 0.38, \mathrm{n}=20)$. At SWC, no differences were found in shallow intergeniculum width $(\bar{x}=2.37 \pm 0.27 \mathrm{~mm}, \mathrm{n}=25)$ and deep intergeniculum width $(\bar{x}=1.82 \pm 0.20, \mathrm{n}=28)$. 
Table 2. Two-way analysis of variance of intergenicula (A) width and (B) length for C. tuberculosum for site (OTPT and SWC) and Depth (3m and 10m).

\begin{tabular}{|cccccc|}
\hline Dependent Variable & Source & DF & MS & F & P \\
\hline \hline \multirow{3}{*}{ (A) Width } & Site & 1 & 7.841 & 3.499 & 0.064 \\
& Depth & 1 & 5.206 & 2.323 & 0.131 \\
& Site * Depth & 1 & 0.2 & 0.089 & 0.766 \\
& Error & 101 & 2.241 & & \\
\hline \multirow{3}{*}{ (B) Length } & Site & 1 & 8.529 & 6.638 & 0.011 \\
& Depth & 1 & 15.819 & 12.312 & 0.001 \\
& Site * Depth & 1 & 14.78 & 11.503 & 0.001 \\
& Error & 101 & 1.285 & & \\
\hline
\end{tabular}

\section{C. tuburculosum Frond Growth}

\section{Length}

Growth rates ranged from 0.92 to $2.63 \mathrm{~mm} \cdot \mathrm{month}^{-1}$ in length (Table 3, Figure 3). The effect of depth on changes (growth) in length was site-specific (site and depth interaction, Table 3, Figure 3). There was no effect of season or site on growth in length (Table 3). A depth effect was also found for growth in length (Table 3). 
Table 3. Monthly growth rates (average $\pm \mathrm{SE}$ ) for $C$. tuberculosum in length ( $\mathrm{mm} \cdot \mathrm{month}$ $\left.{ }^{-1}\right)$ and area $\left(\mathrm{mm}^{2} \cdot\right.$ month $\left.^{-1}\right)$ for season (summer and winter) at Otter Point (OTPT) and Stillwater Cove (SWC).

\begin{tabular}{|cccccc|}
\hline Season & Site & Depth & Length & Area & \\
\hline \multirow{3}{*}{ Summer } & \multirow{2}{*}{ OTPT } & Shallow & $2.41 \pm 0.11$ & $3.05 \pm 0.42$ & $\mathrm{n}=5$ \\
& & Deep & $1.36 \pm 0.09$ & $1.17 \pm 0.15$ & $\mathrm{n}=4$ \\
& \multirow{2}{*}{ SWC } & Shallow & $1.54 \pm 0.24$ & $1.56 \pm 0.34$ & $\mathrm{n}=5$ \\
& & Deep & $1.47 \pm 0.08$ & $2.06 \pm 0.36$ & $\mathrm{n}=5$ \\
\hline \multirow{3}{*}{ Winter } & \multirow{2}{*}{ OTPT } & Shallow & $2.63 \pm 0.36$ & $6.55 \pm 1.89$ & $\mathrm{n}=4$ \\
& & Deep & 1.38 & 1.66 & $\mathrm{n}=1$ \\
& \multirow{2}{*}{ SWC } & Shallow & $1.54 \pm 0.24$ & $1.56 \pm 0.34$ & $\mathrm{n}=5$ \\
& & Deep & $2.03 \pm 0.10$ & $4.09 \pm 0.33$ & $\mathrm{n}=6$ \\
\hline
\end{tabular}

Average apical growth, during summer months (Jul-Sept 2013) at OTPT was significantly greater for shallow $\left(\bar{x}=2.41 \pm 0.11 \mathrm{~mm} \cdot\right.$ month $\left.^{-1}, \mathrm{n}=5\right)$ compared to deep $\left(\bar{x}=1.36 \pm 0.09 \mathrm{~mm} \cdot\right.$ month $\left.^{-1}, \mathrm{n}=4\right)$ individuals (Table 4). During summer months (Jul-Sept 2012) at SWC, shallow individuals $\left(\bar{x}=1.54 \pm 0.24 \mathrm{~mm} \cdot \mathrm{month}^{-1}, \mathrm{n}=5\right)$ were not significantly different in apical growth compared to deep individuals $(\bar{x}=1.47 \pm 0.08$ $\mathrm{mm} \cdot$ month $^{-1}, \mathrm{n}=5$; Figure 3 ).

Growth in length between shallow $\left(\bar{x}=2.63 \pm 0.36 \mathrm{~mm} \cdot\right.$ month $\left.^{-1}\right)$ and deep $(1.38$ $\mathrm{mm} \cdot$ month $^{-1}$ ) individuals was significantly different at OTPT during winter months (November 2012- May 2013) (Table 4, Figure 3A). During winter months at SWC (FebMay 2013), shallow individuals $\left(\bar{x}=1.54 \pm 0.24 \mathrm{~mm} \cdot\right.$ month $\left.^{-1}, \mathrm{n}=2\right)$ grew significantly less compared to deep individuals, $\left(\bar{x}=2.03 \pm 0.10 \mathrm{~mm} \cdot\right.$ month $\left.^{-1}, \mathrm{n}=3\right)$ in length (Table 4, Figure 3B). 
Table 4. Three-way analysis of variance on C.tuberculosum with season, site, and depth for growth measured as (A) length $\left(\mathrm{mm}^{\prime}\right.$ month $\left.{ }^{-1}\right)$ and $(\mathrm{B})$ area $\left(\mathrm{mm}^{2} \cdot \mathrm{month}^{-1}\right)$.

\begin{tabular}{|cccccc|}
\hline Dependent Variable & Source & DF & MS & F & P \\
\hline \hline & Season & 1 & 0.264 & 1.462 & 0.237 \\
& Site & 1 & 0.595 & 3.298 & 0.080 \\
& Depth & 1 & 1.45 & 8.039 & 0.009 \\
(A) Length & Season * Site & 1 & 0.043 & 0.237 & 0.630 \\
& Season * Depth & 1 & 0.054 & 0.299 & 0.589 \\
& Site * Depth & 1 & 3.014 & 16.709 & 0.000 \\
& Season * Site * Depth & 1 & 0.238 & 1.321 & 0.260 \\
& Error & 27 & 0.18 & & \\
\hline & Season & 1 & 14.7 & 6.954 & 0.014 \\
& Site & 1 & 4.064 & 1.923 & 0.177 \\
& Depth & 1 & 5.72 & 2.706 & 0.112 \\
& Season * Site & 1 & 1.558 & 0.737 & 0.398 \\
& Season * Depth & 1 & 0.382 & 0.181 & 0.674 \\
& Site * Depth & 1 & 38.948 & 18.425 & $<0.001$ \\
& Season * Site * Depth & 1 & 10.264 & 4.855 & 0.036 \\
& Error & 27 & 2.114 & & \\
\hline
\end{tabular}

Area

The effect of depth and site on changes in area (growth) was season-specific (season and site and depth interaction, Table 3B, Table 4, Figure 3). A season effect was found for areal growth (Table 3B). Growth in area ranged from 0.76 to $6.55 \mathrm{~mm}^{2} \cdot \mathrm{month}$ ${ }^{1}$ and varied between seasons, season and site, season and depth, and site and depth (Table 4).

Areal growth during summer months (Jul-Sept 2013) at OTPT was similar in shallow individuals $\left(\bar{x}=3.05 \pm 0.42 \mathrm{~mm}^{2} \cdot\right.$ month $\left.^{-1}, \mathrm{n}=5\right)$ and deep $(\bar{x}=1.17 \pm 0.15$ 
$\mathrm{mm}^{2} \cdot$ month $^{-1}, \mathrm{n}=4$; Figure 3). During summer months (Jul-Sept 2012) at SWC, areal growth was not significantly different when shallow individuals $\left(\bar{x}=1.56 \pm 0.34 \mathrm{~mm}^{2}\right.$. month $\left.{ }^{-1}, \mathrm{n}=5\right)$ were compared to deep $\left(\bar{x}=2.06 \pm 0.36 \mathrm{~mm}^{2} \cdot\right.$ month $\left.^{-1}, \mathrm{n}=5\right)$. At OTPT, areal growth during winter months (November 2012- May 2013) was significantly greater in shallow $\left(\bar{x}=6.55 \pm 1.89 \mathrm{~mm}^{2} \cdot\right.$ month $\left.^{-1}, \mathrm{n}=4\right)$ than deep $(1.66$ $\mathrm{mm}^{2} \cdot$ month $^{-1}, \mathrm{n}=1$ ) individuals (Table 4 , Figure $3 \mathrm{~A}$ ). Growth in area at SWC (February 2013-June 2013) was significantly less in shallow $\left(\bar{x}=1.56 \pm 0.34 \mathrm{~mm}^{2}\right.$ month $\left.{ }^{-1}, \mathrm{n}=2\right)$ than deep $\left(\bar{x}=4.09 \pm 0.33 \mathrm{~mm}^{2} \cdot\right.$ month $\left.^{-1}, \mathrm{n}=3\right)$ individuals (Table 4, Figure 3B). Overall, growth in length was generally higher at OTPT than SWC (Table 4. Figure 3). Areal growth at OTPT was higher in shallow individuals than deep, while the opposite pattern occurred at SWC during winter months (Figure 3). 


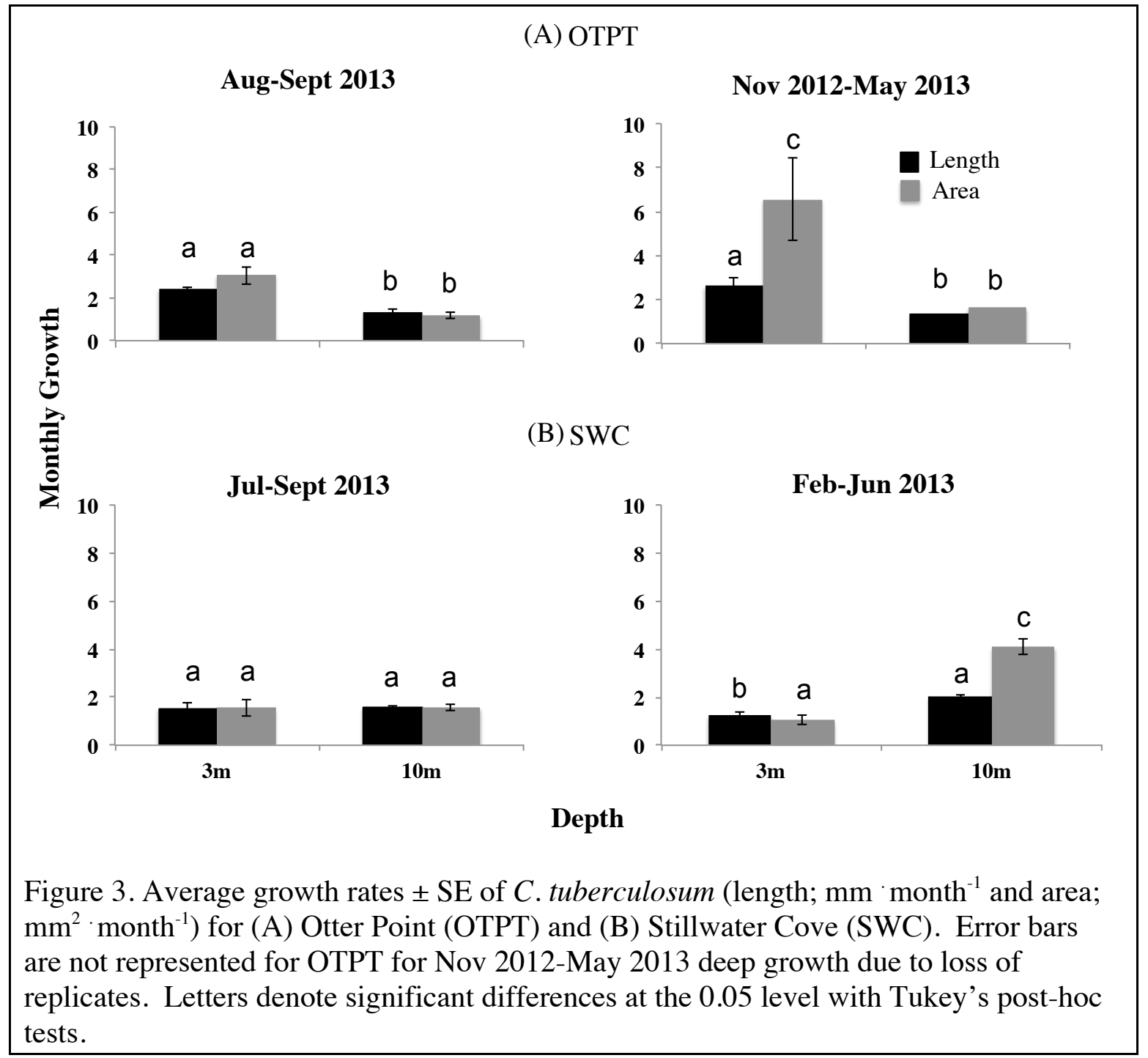

Transplant Experiments

In the transplant experiments, changes in length and area both varied significantly as a function of the interaction between transplant date, depth, and treatment. This interaction was due to differences in growth among specific treatment combinations that were not ecologically relevant (e.g., transplant 1 OTPT shallow control vs. transplant 3 SWC deep transplant control). The focus of multiple transplant experiments was to look 
at temporal variability at OTPT and spatial variability (OTPT and SWC) within the same time frame.

Table 5. Three-way analysis of variance results for $C$. tuberculosum transplant experiments with transplant, depth, and treatment for $(\mathrm{A})$ length $\left(\mathrm{mm} \cdot \mathrm{month}^{-1}\right)$ and (B) area $\left(\mathrm{mm}^{2} \cdot\right.$ month $\left.^{-1}\right)$.

\begin{tabular}{|cccccc}
\hline $\begin{array}{l}\text { Dependent } \\
\text { Variable }\end{array}$ & Source & DF & MS & F & P \\
\hline \hline \multirow{4}{*}{ (A) Length } & Transplant & 2 & 5.891 & 44.717 & $<0.001$ \\
& Depth & 1 & 0.541 & 4.103 & 0.046 \\
& Treatment & 2 & 0.273 & 2.075 & 0.132 \\
& Transplant * Depth & 2 & 1.457 & 11.057 & $<0.001$ \\
& Transplant * Treatment & 4 & 0.397 & 3.014 & 0.022 \\
& Depth * Treatment & 2 & 0.152 & 1.153 & 0.320 \\
& Transplant * Depth * Treatment & 4 & 0.303 & 2.298 & 0.065 \\
& Error & 89 & 0.132 & & \\
\hline & Transplant & 2 & 27.577 & 21.432 & $<0.001$ \\
& Depth & 1 & 8.179 & 6.356 & 0.013 \\
& Treatment & 2 & 2.235 & 1.737 & 0.182 \\
& Transplant * Depth & 2 & 18.792 & 14.604 & $<0.001$ \\
& Transplant * Treatment & 4 & 2.228 & 1.732 & 0.150 \\
& Depth * Treatment & 2 & 0.741 & 0.576 & 0.564 \\
& Transplant * Depth * Treatment & 4 & 3.652 & 2.838 & 0.029 \\
& Error & 89 & 1.287 & & \\
\hline
\end{tabular}

\section{Length}

Transplant 1 was conducted at OTPT during Decemeber 18, 2011-March 10, 2012 (95 days). Growth rates ranged from 0.92 to $1.06 \mathrm{~mm} \cdot \mathrm{month}^{-1}$ in length (Figure 4A, Table 6A). No significant differences were found in length (growth) in transplant 1 between depths or within depths between treatments. Transplant 2 was conducted at OTPT during November 1, 2012-May 31, 2013 (229 days). Growth rates ranged from 
1.50 to $2.63 \mathrm{~mm}^{\text {month }}{ }^{-1}$ in length (Figure $4 \mathrm{~A}$, Table 6B). The reported deep control growth rate was from only one replicate. In order to determine if the deep control value was different than other treatments, confidence intervals (CI) of treatments were used to detect if the deep control length value (1.38) fell within the intervals. The deep control value fell outside of the $\mathrm{CI}$ interval of the transplant controls, where the controls grew more than the transplant controls (individuals removed from $10 \mathrm{~m}$, stained in the lab, and put back at 10m) (Figure 4A). Transplant 3 was conducted at SWC during January 30, 2013-June 17, 2013 (119 days). Growth rates ranged from 1.41 to $2.12 \mathrm{~mm} \cdot \mathrm{month}^{-1}$ in length (Figure 4A, Table 6C). No significant differences were found between growth in length in regards to depth or treatment.

Area

Growth in transplant 1 ranged between 0.76 to $1.46 \mathrm{~mm}^{2} \cdot$ month $^{-1}$ in area (Table 6A). No significant differences were found in apical growth or area between any treatment groups within the experiment (Figure 4B). Growth in area, during transplant 2 ranged between 1.61 to $6.55 \mathrm{~mm}^{2} \cdot$ month $^{-1}$ (Table 6B). Deep control individuals resulted in only one successful replicate out of six. Again, $95 \%$ confidence intervals were used to detect if the deep control area value (1.66) fell with the other treatments. All treatment confidence intervals included the 1.66 value, therefore, no differences were found among treatments in area (growth) (Figure 4B). Growth in area during transplant 3 ranged from 1.04 to $4.09 \mathrm{~mm}^{2} \cdot \mathrm{month}^{-2}$ (Table 6C). Significant differences were found between deep controls and deep transplants, where control individuals (from deep) grew more than the transplanted individuals from shallow in area (Figure 4B, Table 6C). 
Table 6. Monthly growth rates for C.tuberculosum during (A) transplant 1 at Otter Point, (B) transplant 2 at Otter Point, and (C) Transplant 3 at Stillwater Cove. Treatments are represented by $\mathrm{C}$; control, $\mathrm{TC}$; transplant control, and $\mathrm{T}$; transplant.

\begin{tabular}{|c|c|c|c|c|c|}
\hline Experiment & Depth & Treatment & Length & Area & \\
\hline \multirow{6}{*}{ (A) Transplant 1} & \multirow[b]{2}{*}{ Shallow } & $\overline{\mathrm{C}}$ & $1.06 \pm 0.09$ & $0.90 \pm 0.18$ & $\mathrm{n}=7$ \\
\hline & & $\mathrm{TC}$ & $1.07 \pm 0.08$ & $1.40 \pm 0.51$ & $n=4$ \\
\hline & \multirow{4}{*}{ Deep } & $\mathrm{T}$ & $0.98 \pm 0.14$ & $1.46 \pm 0.60$ & $n=7$ \\
\hline & & $\mathrm{C}$ & $0.93 \pm 0.10$ & $0.76 \pm 0.14$ & $n=8$ \\
\hline & & $\mathrm{TC}$ & $1.04 \pm 0.07$ & $0.76 \pm 0.13$ & $n=5$ \\
\hline & & $\mathrm{T}$ & $0.92 \pm 0.03$ & $0.77 \pm 0.06$ & $\mathrm{n}=7$ \\
\hline \multirow{6}{*}{ (B) Transplant 2} & \multirow[b]{2}{*}{ Shallow } & $\mathrm{C}$ & $2.63 \pm 0.39$ & $6.55 \pm 1.89$ & $\mathrm{n}=4$ \\
\hline & & $\mathrm{TC}$ & $1.88 \pm 0.08$ & $3.27 \pm 1.40$ & $n=3$ \\
\hline & \multirow{4}{*}{ Deep } & $\mathrm{T}$ & $2.30 \pm 0.10$ & $3.53 \pm 0.90$ & $\mathrm{n}=2$ \\
\hline & & $\mathrm{C}$ & $1.38 \pm 0.10$ & $1.66 \pm 0.44$ & $\mathrm{n}=1$ \\
\hline & & $\mathrm{TC}$ & $1.65 \pm 0.07$ & $1.49 \pm 0.15$ & $\mathrm{n}=8$ \\
\hline & & $\mathrm{T}$ & $1.50 \pm 0.12$ & $1.61 \pm 0.21$ & $\mathrm{n}=12$ \\
\hline \multirow{6}{*}{ (C) Transplant 3} & \multirow[b]{2}{*}{ Shallow } & $\mathrm{C}$ & $1.24 \pm 0.28$ & $1.04 \pm 0.20$ & $n=2$ \\
\hline & & $\mathrm{TC}$ & $1.93 \pm 0.73$ & $2.11 \pm 0.43$ & $\mathrm{n}=7$ \\
\hline & \multirow{4}{*}{ Deep } & $\mathrm{T}$ & $1.45 \pm 0.11$ & $2.09 \pm 0.70$ & $\mathrm{n}=3$ \\
\hline & & $\mathrm{C}$ & $2.03 \pm 0.09$ & $4.09 \pm 0.39$ & $\mathrm{n}=6$ \\
\hline & & $\mathrm{TC}$ & $2.12 \pm 0.12$ & $2.83 \pm 0.27$ & $\mathrm{n}=11$ \\
\hline & & $\mathrm{T}$ & $1.41 \pm 0.11$ & $1.60 \pm 0.16$ & $\mathrm{n}=10$ \\
\hline
\end{tabular}

Differences were found between transplant 1 and transplant 2 at OTPT, where transplant 2 shallow controls grew more than shallow controls in transplant 1 in apical growth and area (Figure 4). Differences were also found in shallow and deep controls from transplant 2 and shallow and deep controls in transplant 3, indicating a site 
difference in apical growth and area, where OTPT grew more in length and area than SWC (Figure 4).

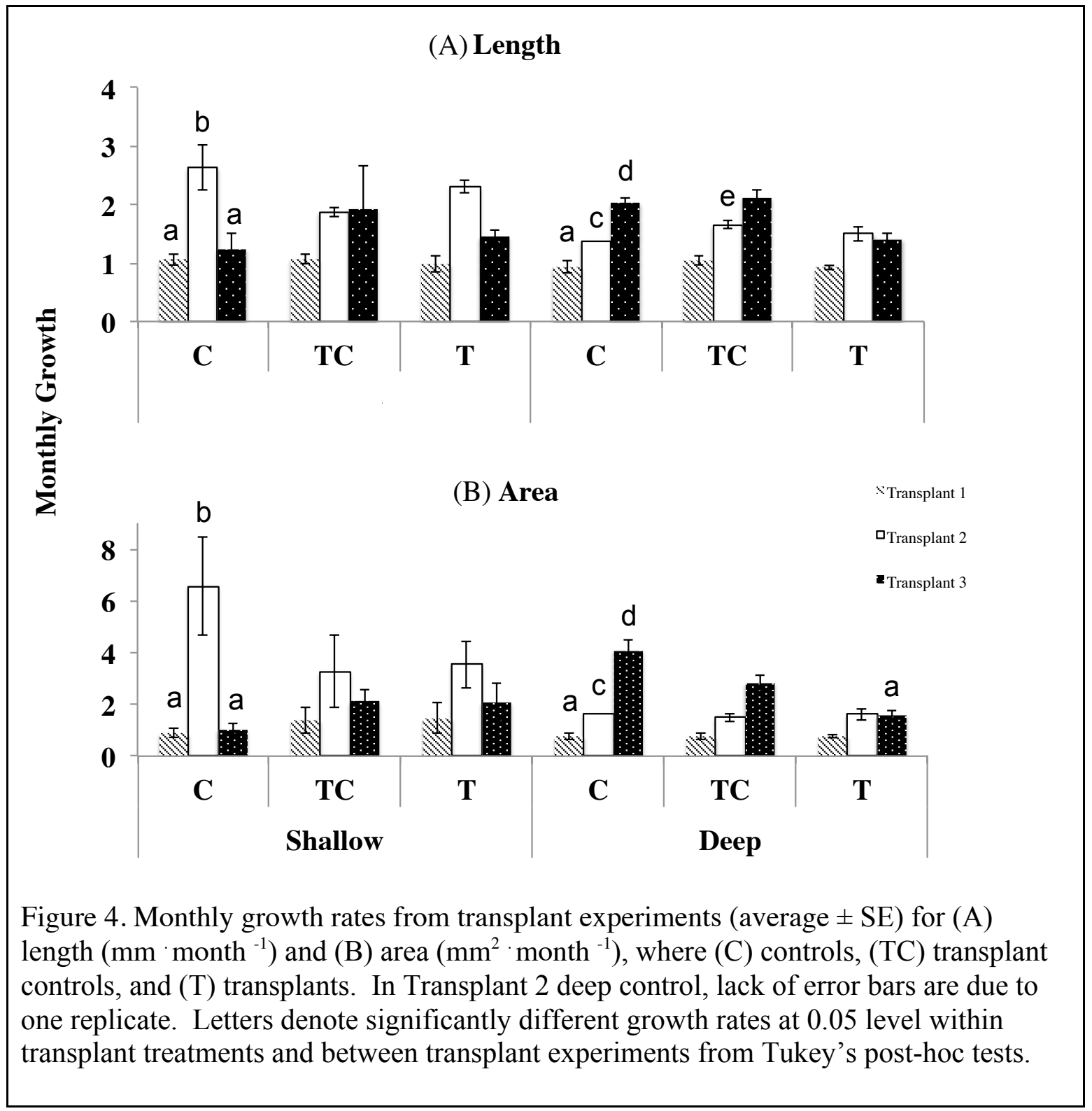




\section{Pigmentation}

Pigment concentration values were generally similar among shallow and deep individuals (Table 7). Changes in pigment concentrations of PE varied significantly as a function of the interaction between season and depth, as well as, season, site and depth. These interactions were due to differences in PE concentrations among specific combinations that were not ecologically interesting (e.g., OTPT deep summer and SWC shallow winter; Table 8). Significant differences were detected between season (PC and APC), site (APC), and depth (APC) (Table 8). The only biologically relevant differences among groups were PC, which differed seasonally, where PC concentrations in SWC shallow individuals were significantly greater during the winter 2013 than summer 2012 (Table 7).

Table 7. Pigment concentrations (average $\mu \mathrm{g} \cdot \mathrm{gDW}^{-1} \pm \mathrm{SE}$, Chl $a$; chlorophyll a, PE; phycoerythrin, PC; phycocyanin, and APC; allophycocyanin) for season (summer and winter), site (OTPT; Otter Point and SWC; Stillwater Cove), and depth (shallow and deep).

\begin{tabular}{|ccccccc|}
\hline Season & Site & Depth & Chl a & PE & PC & APC \\
\hline \hline \multirow{5}{*}{ Summer } & \multirow{2}{*}{ OTPT } & Shallow & $133.2 \pm 4.9$ & $246.3 \pm 16.5$ & $5.7 \pm 0.3$ & $6.5 \pm 0.7$ \\
& & Deep & $138.7 \pm 13.4$ & $232.4 \pm 15.4$ & $4.5 \pm 0.4$ & $4.4 \pm 0.7$ \\
& \multirow{2}{*}{ SWC } & Shallow & $128.0 \pm 6.7$ & $269.1 \pm 16.4$ & $6.5 \pm 0.5$ & $9.0 \pm 1.0$ \\
& & Deep & $141.5 \pm 16.5$ & $192.1 \pm 12.1$ & $4.8 \pm 0.2$ & $7.0 \pm 0.7$ \\
\hline \multirow{4}{*}{ Winter } & \multirow{2}{*}{ OTPT } & Shallow & $152.3 \pm 8.3$ & $211.8 \pm 34.7$ & $12.1 \pm 2.2$ & $8.0 \pm 0.9$ \\
& & Deep & $134.1 \pm 3.5$ & $194.5 \pm 14.9$ & $13.2 \pm 3.4$ & $6.7 \pm 0.8$ \\
& \multirow{2}{*}{ SWC } & Shallow & $155.7 \pm 13.1$ & $223.3 \pm 30.3$ & $26.6 \pm 9.2$ & $13.9 \pm 4.9$ \\
& & Deep & $162.7 \pm 5.7$ & $276.3 \pm 21.4$ & $17.5 \pm 5.2$ & $9.6 \pm 2.1$ \\
\hline
\end{tabular}


Table 8. Multi-factor analysis of variance with season, site, and depth for pigment concentrations (Chl $a$; chlorophyll $a$, PE; phycoerythrin, PC; phycocyanin, and APC; allophycocyanin) for season (summer and winter), site (OTPT; Otter Point and SWC; Stillwater Cove), and depth (shallow and deep).

\begin{tabular}{|c|c|c|c|c|c|}
\hline $\begin{array}{c}\text { Dependent } \\
\text { Variable }\end{array}$ & Source & DF & MS & $\mathrm{F}$ & $P$ \\
\hline \multirow{8}{*}{ (A) $\mathrm{Chl} a$} & Season & 1 & 1948.640 & 2.071 & 0.155 \\
\hline & Site & 1 & 1268.277 & 1.348 & 0.250 \\
\hline & Depth & 1 & 1438.871 & 1.529 & 0.221 \\
\hline & Season * Site & 1 & 1530.809 & 1.627 & 0.207 \\
\hline & Season * Depth & 1 & 495.549 & 0.527 & 0.471 \\
\hline & Site $*$ Depth & 1 & 2654.700 & 2.821 & 0.098 \\
\hline & Season $*$ Site $*$ Depth & 1 & 66.709 & 0.071 & 0.791 \\
\hline & Error & 64 & 941.047 & & \\
\hline \multirow{8}{*}{ (B) $\mathrm{PE}$} & Season & 1 & 1289.129 & 0.293 & 0.590 \\
\hline & Site & 1 & 6369.684 & 1.448 & 0.233 \\
\hline & Depth & 1 & 3387.176 & 0.770 & 0.384 \\
\hline & Season * Site & 1 & 13616.866 & 3.095 & 0.083 \\
\hline & Season * Depth & 1 & 17782.235 & 4.042 & 0.049 \\
\hline & Site * Depth & 1 & 54.888 & 0.012 & 0.911 \\
\hline & Season $*$ Site $*$ Depth & 1 & 19705.338 & 4.479 & 0.038 \\
\hline & Error & 64 & 4399.721 & & \\
\hline \multirow{8}{*}{ (C) $\mathrm{PC}$} & Season & 1 & 2481.913 & 18.289 & 0.000 \\
\hline & Site & 1 & 418.465 & 3.084 & 0.084 \\
\hline & Depth & 1 & 145.438 & 1.072 & 0.304 \\
\hline & Season * Site & 1 & 326.605 & 2.407 & 0.126 \\
\hline & Season * Depth & 1 & 33.541 & 0.247 & 0.621 \\
\hline & Site * Depth & 1 & 140.214 & 1.033 & 0.313 \\
\hline & Season $*$ Site $*$ Depth & 1 & 115.725 & 0.853 & 0.359 \\
\hline & Error & 64 & 135.702 & & \\
\hline \multirow{8}{*}{ (D) APC } & Season & 1 & 139.419 & 5.580 & 0.021 \\
\hline & Site & 1 & 217.434 & 8.702 & 0.004 \\
\hline & Depth & 1 & 107.725 & 4.311 & 0.042 \\
\hline & Season * Site & 1 & 15.581 & 0.624 & 0.433 \\
\hline & Season * Depth & 1 & 2.671 & 0.107 & 0.745 \\
\hline & Site * Depth & 1 & 9.649 & 0.386 & 0.537 \\
\hline & Season $*$ Site $*$ Depth & 1 & 10.479 & 0.419 & 0.520 \\
\hline & Error & 64 & 24.987 & & \\
\hline
\end{tabular}


Pigment ratios were calculated to examine changes in concentrations relative to season (Table 9). The effect of season was significantly greater for PE:PC and PE:Chl $a$ ratios during the summer and PC:APC ratios during the winter (Table 10).

Table 9. Pigment ratios (PE; phycoerythrin, PC; phycocyanin, APC; allophycocyanin, and Chl $a$; chlorophyll $a$ ) for season (summer and winter), site (OTPT; Otter Point and SWC; Stillwater Cove), and depth (shallow and deep).

\begin{tabular}{|ccccccc|}
\hline Season & Site & Depth & PE:PC & PC:APC & PE:Chl a & \\
\hline \multirow{4}{*}{ Summer } & OTPT & Shallow & $43.04 \pm 1.69$ & $0.92 \pm 0.06$ & $1.67 \pm 0.14$ & $\mathrm{n}=9$ \\
& & Deep & $55.44 \pm 7.69$ & $1.11 \pm 0.11$ & $1.74 \pm 0.11$ & $\mathrm{n}=7$ \\
& \multirow{2}{*}{ SWC } & Shallow & $41.92 \pm 2.45$ & $0.78 \pm 0.07$ & $1.90 \pm 0.07$ & $\mathrm{n}=10$ \\
& & Deep & $40.30 \pm 2.30$ & $0.73 \pm 0.06$ & $1.32 \pm 0.10$ & $\mathrm{n}=10$ \\
\hline \multirow{3}{*}{ Winter } & \multirow{2}{*}{ OTPT } & Shallow & $27.60 \pm 5.87$ & $1.93 \pm 0.40$ & $1.25 \pm 0.20$ & $\mathrm{n}=10$ \\
& & Deep & $25.94 \pm 4.78$ & $1.97 \pm 0.35$ & $1.27 \pm 0.11$ & $\mathrm{n}=10$ \\
& \multirow{2}{*}{ SWC } & Shallow & $16.24 \pm 4.84$ & $1.97 \pm 0.23$ & $1.54 \pm 0.21$ & $\mathrm{n}=9$ \\
& & Deep & $26.54 \pm 5.82$ & $1.99 \pm 0.34$ & $1.53 \pm 0.11$ & $\mathrm{n}=10$ \\
\hline
\end{tabular}


Table 10. Multi-factor analysis of variance of season, site, and depth for pigment ratios (PE:PC; phycoerthyrin:phycocyanin, PC:APC; phycocyanin:allophycocyanin, and PE:Chl $a$; phycoerythrin:chlorophyll $a$ ).

\begin{tabular}{|c|c|c|c|c|c|}
\hline $\begin{array}{c}\text { Dependent } \\
\text { Variable }\end{array}$ & Source & $\mathrm{DF}$ & MS & $\mathrm{F}$ & $\mathrm{P}$ \\
\hline \multirow{8}{*}{ (A) PE:PC } & Season & 1 & 7601.082 & 36.766 & $<0.001$ \\
\hline & Site & 1 & 650.189 & 3.145 & 0.081 \\
\hline & Depth & 1 & 396.433 & 1.918 & 0.171 \\
\hline & Season*Site & 1 & 37.61 & 0.182 & 0.671 \\
\hline & Season * Depth & 1 & 24.845 & 0.12 & 0.730 \\
\hline & Site * Depth & 1 & 10.199 & 0.049 & 0.825 \\
\hline & Season $*$ Site $*$ Depth & 1 & 627.303 & 3.034 & 0.086 \\
\hline & Error & 63 & 206.741 & & \\
\hline \multirow{8}{*}{ (B) PC:APC } & Season & 1 & 21.018 & 33.17 & $<0.001$ \\
\hline & Site & 1 & 0.252 & 0.397 & 0.531 \\
\hline & Depth & 1 & 0.045 & 0.07 & 0.792 \\
\hline & Season*Site & 1 & 0.366 & 0.578 & 0.450 \\
\hline & Season*Depth & 1 & 0.003 & 0.005 & 0.943 \\
\hline & Site*Depth & 1 & 0.111 & 0.175 & 0.677 \\
\hline & Season*Site*Depth & 1 & 0.114 & 0.18 & 0.673 \\
\hline & Error & 63 & 0.634 & & \\
\hline \multirow{8}{*}{ (C) PE:Chl $a$} & Season & 1 & 1.382 & 7.79 & 0.007 \\
\hline & Site & 1 & 0.115 & 0.65 & 0.423 \\
\hline & Depth & 1 & 0.288 & 1.621 & 0.208 \\
\hline & Season*Site & 1 & 0.657 & 3.701 & 0.059 \\
\hline & Season*Depth & 1 & 0.32 & 1.802 & 0.184 \\
\hline & Site*Depth & 1 & 0.372 & 2.096 & 0.153 \\
\hline & Season*Site*Depth & 1 & 0.34 & 1.918 & 0.171 \\
\hline & Error & 63 & 0.177 & & \\
\hline
\end{tabular}




\section{Physiological Parameters}

Irradiance data taken from both sites at $3 \mathrm{~m}$ ranged from 200-800 $\mu$ mol photons $\mathrm{m}^{-2} \cdot \mathrm{s}^{-1}$ and $10-100 \mu \mathrm{mol}$ photons $\cdot \mathrm{m}^{-2} \cdot \mathrm{s}^{-1}$ at $10 \mathrm{~m}$. Maximum photosynthetic rates $\left(\mathrm{P}_{\max }\right)$, alpha $(\alpha)$ and respiration rates were generally higher in shallow individuals than deep individuals (Figure 5). Compensation irradiances ranged between 4-6 $\mu$ mol photons $\mathrm{m}^{-2} \cdot \mathrm{s}^{-1}$ and saturation irradiances between 13-28 $\mu \mathrm{mol}$ photons $\mathrm{m}^{-2} \cdot \mathrm{s}^{-1}$. Although significance was detected in multiple effects as well as, their interactions (Table 10), the only biologically relevant comparison was for $\mathrm{P}_{\max }$ with shallow individuals at SWC during the summer having lower maximum photosynthetic rates than shallow individuals at SWC during winter (Table 11).

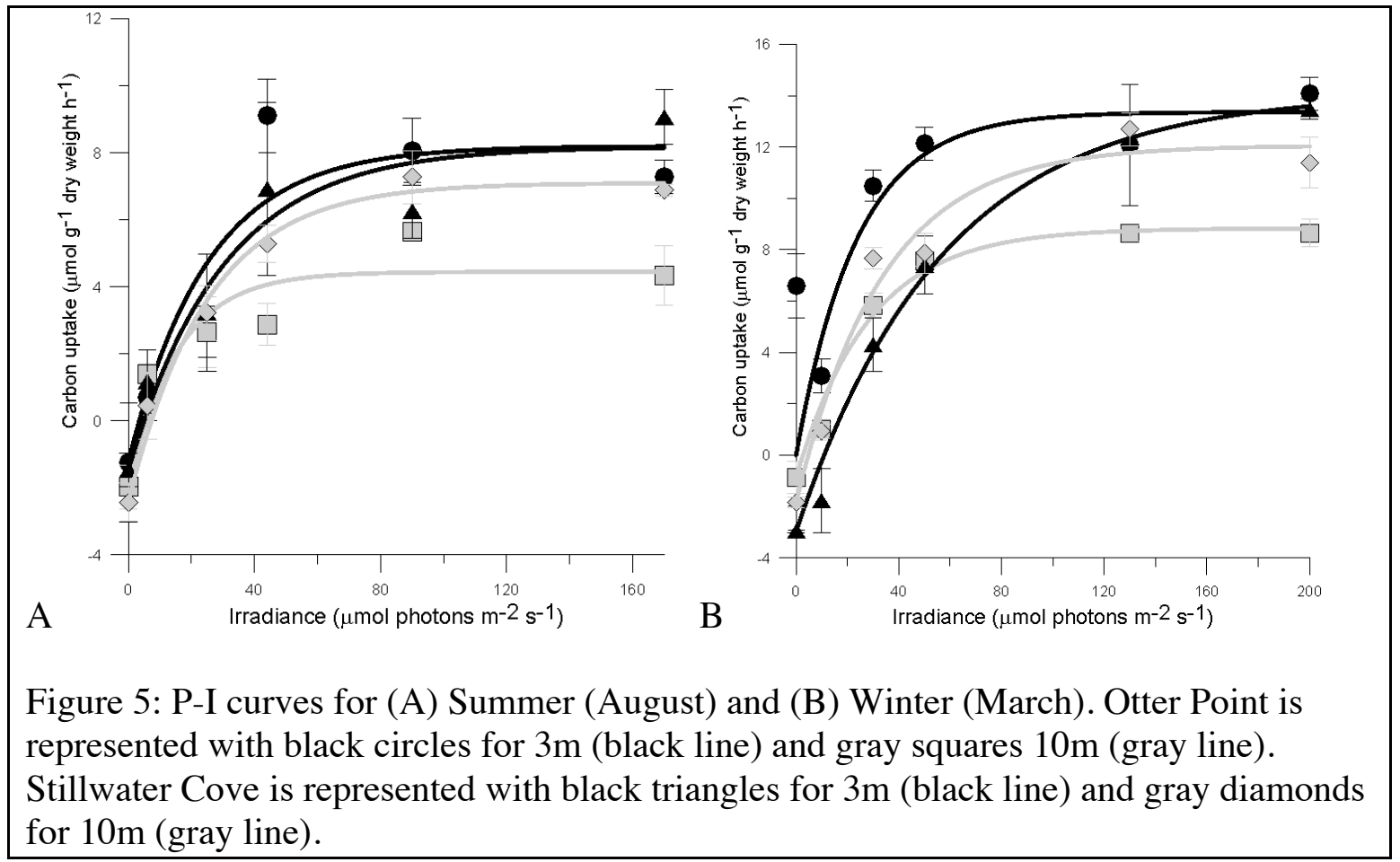




\section{Maximum photosynthetic rate $\left(\mathrm{P}_{\max }\right)$}

A one-way ANOVA with season, site, and depth groups was used to determine if photosynthetic maximum rates were significantly different $(\mathrm{P}<0.001)$. At OTPT, shallow individuals $\left(\bar{x}=9.41 \pm 1.05 \mu \mathrm{mol} \mathrm{C} \cdot \mathrm{gDW}^{-1} \cdot \mathrm{h}^{-1}, \mathrm{n}=3\right)$ had a maximum photosynthetic rate that was not significantly different compared to deep individuals $(\bar{x}=$ $6.76 \pm 0.56 \mu \mathrm{mol} \mathrm{C} \cdot \mathrm{gDW}^{-1} \cdot \mathrm{h}^{-1}, \mathrm{n}=3$; Table 10). $\mathrm{P}_{\max }$ values for $\mathrm{SWC}$ were not significantly different between shallow individuals $\left(\bar{x}=9.63 \pm 1.20 \mu \mathrm{mol} \mathrm{C} \cdot \mathrm{gDW}^{-1} \cdot \mathrm{h}\right.$ $\left.{ }^{1}, \mathrm{n}=3\right)$ and deep individuals $\left(\bar{x}=9.50 \pm 0.66 \mu \mathrm{mol} \mathrm{C} \cdot \mathrm{gDW}^{-1} \cdot \mathrm{h}^{-1}, \mathrm{n}=3\right.$; Table 10$)$. During the winter, shallow individuals $\left(\bar{x}=13.49 \pm 1.28 \mu \mathrm{mol} \mathrm{C} \cdot \mathrm{gDW}^{-1} \cdot \mathrm{h}^{-1}, \mathrm{n}=3\right)$ at OTPT were significantly greater in $\mathrm{P}_{\max }$ than deep individuals $(\bar{x}=9.75 \pm 0.65 \mu \mathrm{mol} \mathrm{C}$ $\mathrm{gDW}^{-1} \cdot \mathrm{h}^{-1}, \mathrm{n}=3 ; \mathrm{P}=0.013$; Table 11$)$. No significant differences were found at SWC during the winter, where $\mathrm{P}_{\max }$ for shallow individuals $\left(\bar{x}=16.14 \pm 1.05 \mu \mathrm{mol} \mathrm{C} \cdot \mathrm{gDW}^{-1}\right.$. $\left.\mathrm{h}^{-1}, \mathrm{n}=3\right)$ were similar to deep individuals $\left(\bar{x}=13.92 \pm 0.54 \mu \mathrm{mol} \mathrm{C} \cdot \mathrm{gDW}^{-1} \cdot \mathrm{h}^{-1}, \mathrm{n}=\right.$ 3, Table 11). Comparing sites, during winter, SWC deep individuals had significnatly greater $\mathrm{P}_{\max }$ values than OTPT $(\mathrm{P}=0.006$; Table 12). Seasonally, shallow individuals at OTPT during the winter had significantly greater $\mathrm{P}_{\max }$ values than shallow individuals during the summer $(\mathrm{P}=0.007$; Table 12$)$. This was a consistent pattern at $\mathrm{SWC}$ as well, where shallow individuals during the winter had sigificantly greater $\mathrm{P}_{\max }$ values compared to shallow individuals during the summer $(\mathrm{P}>0.001$; Table 12$)$. 


\section{Photosynthetic efficiency (alpha)}

A one-way ANOVA with season, site, and depth groups was used to determine if alpha values were significantly different $(\mathrm{P}=0.078)$. Photosynthetic efficiency (alpha) at OTPT during the summer was not significantly different between shallow individuals $(\bar{x}$ $=0.38 \pm 0.02, \mathrm{n}=3)$ and deep individuals $(\bar{x}=0.30 \pm 0.13, \mathrm{n}=3$; Table 11). At SWC, alpha also showed no difference between shallow $(\bar{x}=0.34 \pm .04, \mathrm{n}=3)$ and deep $(\bar{x}=$ $0.39 \pm 0.01, \mathrm{n}=3$ ) individuals during the summer (Table 11). During the winter at OTPT, alpha was not significantly different in shallow individuals $(\bar{x}=0.57 \pm 0.07, \mathrm{n}=$ 3) than deep individuals $(\bar{x}=0.31 \pm 0.07, \mathrm{n}=3$; Table 11). At SWC, alpha showed no significant differences between shallow individuals $(\bar{x}=0.28 \pm 0.07, \mathrm{n}=3)$ and deep individuals $(\bar{x}=0.41 \pm 0.03, \mathrm{n}=3$; Table 11).

\section{Respiration}

A one-way ANOVA with season, site, and depth groups was used to determine if respiration rates were significantly different $(\mathrm{P}=0.181)$. Respiration rates did not differ between shallow $\left(\bar{x}=-2.33 \mu \mathrm{mol} \pm 1.01 \mu \mathrm{mol} \mathrm{C} \cdot \mathrm{gDW}^{-1} \cdot \mathrm{h}^{-1}, \mathrm{n}=3\right)$ and deep $(\bar{x}=-1.98$ $\pm 0.65 \mu \mathrm{mol} \mathrm{C} \cdot \mathrm{gDW}^{-1} \cdot \mathrm{h}^{-1}, \mathrm{n}=3$; Table 11$)$ at OTPT during the summer. At SWC, average respiration rates did not significantly differ between shallow individuals $(\bar{x}=-$ $\left.1.47 \pm 0.35 \mu \mathrm{mol} \mathrm{C} \cdot \mathrm{gDW}^{-1} \cdot \mathrm{h}^{-1}, \mathrm{n}=3\right)$ and deep individuals $(\bar{x}=-2.43 \pm 0.40 \mu \mathrm{mol} \mathrm{C}$ $\mathrm{gDW}^{-1} \cdot \mathrm{h}^{-1}, \mathrm{n}=3$; Table 11$)$. Occasionally, during winter incubations at OTPT respiration data was positive and those data were removed from the analysis. Respiration rates at SWC for shallow individuals $\left(\bar{x}=-2.97 \pm 0.07 \mu \mathrm{mol} \mathrm{C} \cdot \mathrm{gDW}^{-1} \cdot \mathrm{h}^{-1}, \mathrm{n}=3\right)$ were 
not significantly different than deep individuals $\left(\bar{x}=-1.84 \pm 0.20 \mu \mathrm{mol} \mathrm{C} \cdot \mathrm{gDW}^{-1} \cdot \mathrm{h}^{-1}, \mathrm{n}\right.$ $=3$; Table 11).

Table 11. Average $\pm \mathrm{SE}$ for respiration rates, maximum photosynthetic rates $\left(\mathrm{P}_{\max }\right)$, alpha $(\alpha)$ for season (summer and winter), site (OTPT; Otter Point and SWC; Stillwater Cove), and depth (shallow and deep).

\begin{tabular}{|cccccc|}
\hline \multicolumn{1}{c}{ Season } & Site & Depth & Respiration & $\mathrm{P}_{\max }$ & $\alpha$ \\
\hline \multirow{3}{*}{ Summer } & \multirow{2}{*}{ OTPT } & Shallow & $-2.33 \pm 1.01$ & $9.41 \pm 1.28$ & $0.38 \pm 0.02$ \\
& & Deep & $-1.98 \pm 0.65$ & $6.76 \pm 0.56$ & $0.30 \pm 0.13$ \\
& \multirow{2}{*}{ SWC } & Shallow & $-1.47 \pm 0.35$ & $9.63 \pm 1.20$ & $0.33 \pm 0.04$ \\
& & Deep & $-2.43 \pm 0.40$ & $9.50 \pm 0.66$ & $0.39 \pm 0.01$ \\
\hline \multirow{3}{*}{ Winter } & \multirow{2}{*}{ OTPT } & Shallow & ND & $13.49 \pm 1.28$ & $0.57 \pm 0.07$ \\
& & Deep & $-1.50 \pm 0.05$ & $9.75 \pm 0.65$ & $0.31 \pm 0.07$ \\
& \multirow{2}{*}{ SWC } & Shallow & $-2.97 \pm 0.07$ & $16.14 \pm 1.05$ & $0.29 \pm 0.07$ \\
& & Deep & $-1.84 \pm 0.20$ & $13.92 \pm 0.54$ & $0.41 \pm 0.03$ \\
\hline
\end{tabular}

\section{Calcification}

Calcification rates ranged from 1.45 to $4.23 \mu \mathrm{mol} \mathrm{CaCO}_{3} \cdot \mathrm{gDW}^{-1} \cdot \mathrm{h}$ (Table 12).

The effect of the interaction of season and depth was significantly greater for calcification rates in shallow individuals than deep individuals and the difference increased during the winter (Table 13). In addition, the site effect showed SWC calcification rates were significantly greater than OTPT (Table 13). Average calcification rates at OTPT during the summer were not significantly different for shallow individuals $\left(\bar{x}=1.97 \pm 0.19 \mu \mathrm{mol} \mathrm{CaCO}_{3} \cdot \mathrm{gDW}^{-1} \cdot \mathrm{h}^{-1}, \mathrm{n}=3\right)$ compared to deep $\left(\bar{x}=1.45 \pm 0.12 \mu \mathrm{mol} \mathrm{CaCO} 3 \cdot \mathrm{gDW}^{-1} \cdot \mathrm{h}^{-1}, \mathrm{n}=3\right.$; Figure 6, Table 12). The same was found at SWC, where calcification rates of shallow individuals $(\bar{x}=2.84 \pm 0.13 \mu \mathrm{mol}$ 
$\left.\mathrm{CaCO}_{3} \cdot \mathrm{gDW}^{-1} \cdot \mathrm{h}^{-1}, \mathrm{n}=3\right)$ were similar to deep individuals $\left(\bar{x}=2.30 \pm 0.07 \mu\right.$ mol $\mathrm{CaCO}_{3}$ $\mathrm{gDW}^{-1} \cdot \mathrm{h}^{-1}, \mathrm{n}=3$; Figure 6 , Table 12).

Table 12. Calcification rates (average $\pm \mathrm{SE}$ ) for season (summer and winter), site (OTPT; Otter Point and SWC; Stillwater Cove), and depth (shallow and deep).

\begin{tabular}{|cccc|}
\hline Season & Site & Depth & $\mu \mathrm{mol} \mathrm{CaCO}{ }^{\prime} \mathrm{gDW}^{-1} \mathrm{~h}^{-1}$ \\
\hline \hline \multirow{4}{*}{ Summer } & \multirow{2}{*}{ OTPT } & Shallow & $1.97 \pm 0.19$ \\
& & Deep & $1.45 \pm 0.12$ \\
& \multirow{2}{*}{ SWC } & Shallow & $2.84 \pm 0.13$ \\
& & Deep & $2.30 \pm 0.07$ \\
\hline \multirow{3}{*}{ Winter } & \multirow{2}{*}{ OTPT } & Shallow & $4.23 \pm 0.39$ \\
& & Deep & $2.34 \pm 0.19$ \\
& \multirow{2}{*}{ SWC } & Shallow & $4.11 \pm 0.06$ \\
& & Deep & $3.06 \pm 0.24$ \\
\hline
\end{tabular}

During the winter, OTPT calcification rates were significantly greater in shallow individuals $\left(\bar{x}=4.23 \pm 0.39 \mu \mathrm{mol} \mathrm{CaCO}_{3} \cdot \mathrm{gDW}^{-1} \cdot \mathrm{h}^{-1}, \mathrm{n}=3\right)$ compared to deep individuals $\left(\bar{x}=2.34 \pm 0.19 \mu \mathrm{mol} \mathrm{CaCO}_{3} \cdot \mathrm{gDW}^{-1} \cdot \mathrm{h}^{-1}, \mathrm{n}=3\right.$; Figure 6, Table 13). The same pattern was found at SWC where shallow individuals $\left(\bar{x}=4.11 \pm 0.06 \mu \mathrm{mol} \mathrm{CaCO}_{3}\right.$ $\left.\mathrm{gDW}^{-1} \cdot \mathrm{h}^{-1}, \mathrm{n}=3\right)$ had significantly higher calcification rates than deep individuals $(\bar{x}=$ $3.06 \pm 0.24 \mu \mathrm{mol} \mathrm{CaCO}_{3} \cdot \mathrm{gDW}^{-1} \cdot \mathrm{h}^{\cdot-1}, \mathrm{n}=3$; Figure 6 , Table 13). Additionally, during the winter, OTPT and SWC shallow individuals had significantly higher calcification rates than deep individuals their respectivtive sites (Figure 6). There was no siginficant differences found among depths during summer. 
Table 13. Analysis of variance with season, site, and depth for calcification rate.

\begin{tabular}{ccccl|}
\hline Source & DF & MS & F & \multicolumn{1}{c}{ P } \\
\hline \hline Season & 1 & 9.44 & 80.313 & $<0.001$ \\
Site & 1 & 1.881 & 16.002 & 0.001 \\
Depth & 1 & 5.596 & 47.61 & $<0.001$ \\
Season * Site & 1 & 0.435 & 3.698 & 0.074 \\
Season * Depth & 1 & 1.24 & 10.553 & 0.005 \\
Site * Depth & 1 & 0.238 & 2.023 & 0.175 \\
Season * Site * Depth & 1 & 0.259 & 2.208 & 0.158 \\
Error & 15 & 0.118 & & \\
Total & 23 & & & \\
\hline
\end{tabular}

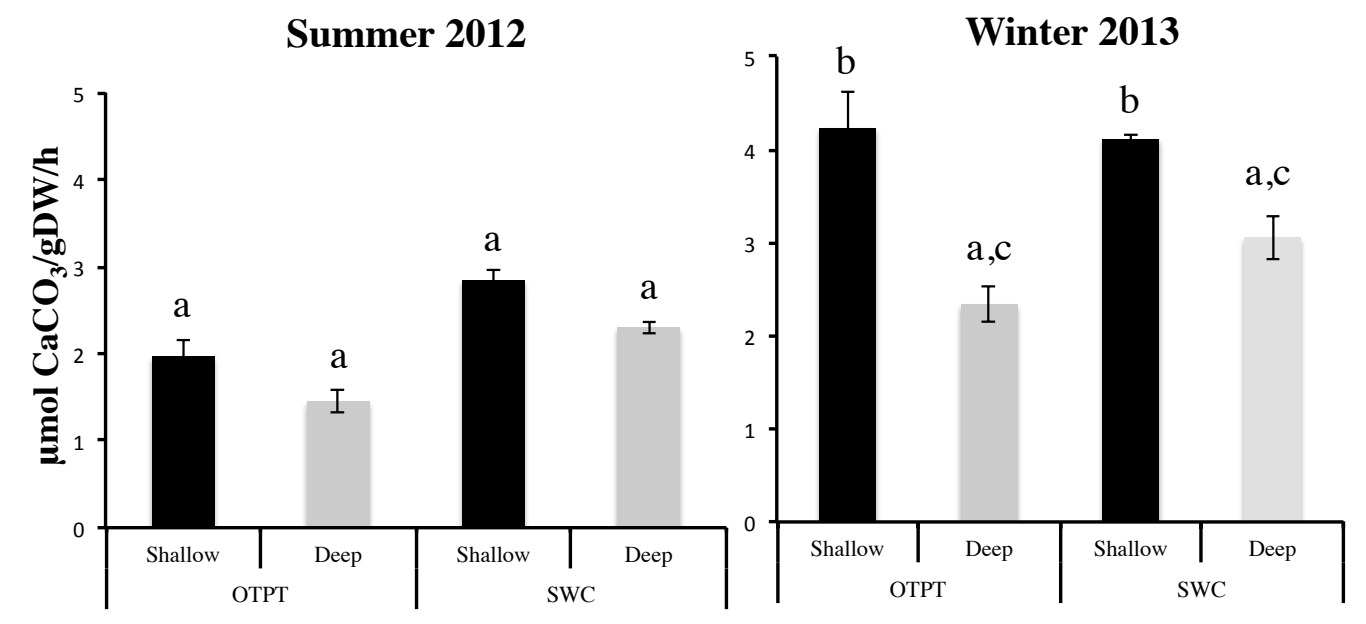

Location

Figure 6: August 2012 and March 2013 calcification rates $\left(\mu \mathrm{mol} \mathrm{CaCO}_{3} \cdot \mathrm{gDW}^{-1} \cdot \mathrm{h}^{-1}\right)$ at $200 \mu \mathrm{mol}$ photons $\cdot \mathrm{m}^{-2} \cdot \mathrm{s}^{-1}$ for shallow and deep individuals at Otter Point (OTPT) and Stillwater Cove (SWC). Letters denote significance between growth in length and area at the 0.05 level from Tukey's post-hoc tests.

\section{Discussion}


The most prominent pattern found between shallow and deep individuals was the number of branch tips, where shallow individuals had a greater average number of branch tips than deep individuals at both sites. This resulted in higher frond weights and total biomass $\mathrm{m}^{-2}$ when comparing shallow to deep individuals. The average total length and total width of individuals were similar between the two popluations (shallow and deep) and may imply that at a certain length, shallow individuals allocate additional energy (from greater irradiances) into forming branch tips. Shallow individuals are likely to experience saturating irradiances for longer periods during the day compared to their deep counterparts. Ultimately, this may give shallow individuals a competitive advantage to occupy shallow water (Harrold et al. 1988). The consistent removal of kelp recruits in shallow water by water motion (Graham 1997) may allow them to dominate shallow wave-exposed habitats, while at deeper depths, light availability is diminished and competition pressure is higher.

Intergenicula morphology is variable and has the abiliity to grow in adaptable shapes and sizes. SWC shallow individuals had longer intergenicula compared to shallow individuals at SWC. Within site differences in intergenicula length were only found at OTPT where deep individual intergenicula were longer than shallow individuals. This pattern was expected for both sites but was not observed at SWC. Due to difficulites in post processing analysis, length and width of a single intergenicula was not taken. For future studies, these parameters should be taken from the same intergenicula for length:width ratio to further look at intergenicula morphology. In studies on a calcified green alga, Halimeda tuna, depth-dependent changes in morphology occurred 
with an increase in the number of branches and number of segments in shallow individuals (Mariani Colombo et al. 1976), as well as thinner segments, larger utricles, and thinner cell walls than shallow plants (Colombo and Orsenigo 1977). In this study, intergenicula were highly variable in shape and size, and on a single individual, different branches exhibited drastically different intergenicula morphology.

Each growth experiment was conducted on varying time scales (weeks-months) because of logistical restraints. In situ growth studies ranged from 20 days to 229 days. Overall, growth was highly variable with differences detected between depth in apical length and area. OTPT shallow individuals grew faster than deep individuals during both seasons. This is likely due to greater light availablity at shallower depths. SWC had the opposite pattern where deep individuals grew faster than shallow. This was surprising due to the presence of $P$. californica at deeper depths. All average apical growth rates were within the range found by Johansen and Austin (1970) at a similar site on the central coast.

Transplant experiments were used to detect differences between apical growth and area with individuals transplanted from shallow to deep and deep to shallow on varying time scales between November and June during multiple years. Overall, differences were found in growth between shallow and deep individuals in 2 out of 3 transplant experiments. The pattern was not consistent in one direction, where at OTPT, shallow individuals grew more than deep and at SWC, deep individuals grew more than shallow indivduals. In terms of treatment effects, deep treatments varied in growth for length with transplant controls growing more than controls at OTPT and growth in area, 
where controls grew more than transplants at SWC. There were no consistent patterns in treatment effects during each experiment. Growth in length and area is highly variable with depth effects detected.

Differences in growth between transplant 1 and 2 indicate annual variability, where conditions may have been more favorable in the winter and spring months during November 2012 through May 2013 than December 2011 through March 2012. Winter months between 2012 and 2013 were unusually dry and the absence of rainfall may have contributed to less turbid waters (more available light) during that time compared to the winter of 2011 and 2012. Differences between transplant 2 and 3 indicate site variability where OTPT shallow individuals had higher growth rates compared to SWC shallow individuals.

During transplant experiments in this current study, $80 \%$ of individual fronds had re-grew new branches at their basal intergeniculum (where they had been plucked from their basal crust in preparation for transplants). This suggests that disturbance may create more branches. Shallow individuals experience higher water motion (Graham 1997) (more disturbance) than deep populations and the combination of water motion and saturating irradiances may give these shallow populations the competitive edge by growing more branches and being highly reproductive. Moreover, Graham (1997) indicated the water motion in shallow areas $(\leq 2.5 \mathrm{~m})$ limits the continuous establishment of kelp canopies and allows persistence and dominance of algal turf in these areas. 
Pigment concentrations were highly variable but did not differ significantly among depths, sites, and seasons in $\mathrm{Chl} a, \mathrm{PE}$, and APC. Seasonally, PC was greater in the winter than summer at SWC, suggesting that synthesis of photosynthetic pigments was generally equal between shallow and deep individuals, from OTPT and SWC, and during summer and winter. Chlorophyll $a$ was generally higher during winter months as reflected in PE:Chl $a$ ratios. Changes in light quantity and quality can directly affect the size and shape of phycobilisomes (Lobban and Harrison 1997). The decrease in PE:PC during the winter may suggest a reduction in rod length while an increase in PC:APC suggests an increase in rod number (Luder et al. 2001). In other studies of red algae, seasonal changes in PE:Chl were found with increasing ratios in winter compared to summer (Kirk 2011). PE:Chl ratios found in this study were the opposite with higher ratios during the summer. Accessory pigments can increase when light availability decreases, more so than chlorophyll $a$ (Dring 1990). In addition, as light intensity decreases (with spectral quanlity unaltered), biliprotein/chl ratios tend to increase (Kirk 2011). During the summer along the Monterey Peninsula, light availablity can decrease drastically with growth of canopy-forming species in shallow and deep water (Clark et al. 2004). In shallow water, neighboring fronds (of individuals located at a deeper depth) can extend over a wide area to shade out light (pers. obs).

Quantifying the physiological performances of these two populations provides baseline data on C. tuberculosum along the Monterey Peninsula. Respiration was not significantly different betweeen depths at a site, between sites, nor seasons. No respiration rates were calculated for shallow individuals at OTPT during the winter. 
Those replicates resulted in a drawdown of $\mathrm{TCO}_{2}$, which was likely explained by "leaky" light infiltration to those samples. Given that corallines have a low compensation irradiance (found in this study), the amount of light required for photosynthesis ( 10 $\mu \mathrm{mol} / \mathrm{m}^{2} / \mathrm{s}$ ) was likely available.

Seasonally, both OTPT and SWC had significantly higher maximum photosynthetic rates during the winter for shallow individuals compared to shallow individuals during the summer. A similar pattern was found in a free-living coralline species, Lithothamnion corallioides, where primary production rates were twice as high in January and February compared to August (Martin et al. 2006). This physiological difference could partially explain the increase in growth during these months when light availability was greater due to the absence of other canopy forming algae. Alpha did not significantly differ suggesting that the rate at which light energy was being converted to chemical energy was generally the same within populations at a site, between sites, and seasonally. Compensation irradiances were similar, indicating individuals at shallow depths "turn on" at the same light level as indivduals in deeper waters. Saturation irriadiances were also similar suggesting that shallow and deep individuals reached their respective maximum photosynthetic rates at the same light level.

There was a general pattern of higher calcification rates in shallow individuals compared to deep individuals at both sites during the winter. This was likely due to the greater availability of light at shallower depths. Additionally, individuals exhibited significant seasonal differences with a higher calcification rate occuring during winter months in shallow individuals but not deep individuals. Calcification had a positive 
correlation to photosynthetic rates in Corallina officinalis (Pentecost 1978, Lobban and Harrison 1997). The increase of the calcification rates in shallow individuals during the winter may be explained by the higher maximum photosynthetic rates found in these individuals.

Using the biomass $\left(\mathrm{kg} \cdot \mathrm{m}^{-2}\right)$ and calcification rate data from this study, extrapolations were made for $\mathrm{kg}$ of $\mathrm{CaCO}_{3}$ accretion per year at those sites along the Monterey Peninsula. An estimated $21 \mathrm{~kg}$ of $\mathrm{CaCO}_{3} \cdot \mathrm{m}^{2} \cdot$ year can be produced from $C$. tuberculosum, along the Monterey Peninsula at shallow depths during the summer. Because calcification rates generally doubled in winter, at shallow depths, $42 \mathrm{~kg}$ of $\mathrm{CaCO}_{3} \cdot \mathrm{m}^{2}$ year can be accumulated. Shallow populations of corallines in wave exposed areas have been described as "thickets" where multiple frond, branch tip, or thalli have reattached to either itself, another individual, and or any other substrate to create a tangled web of corallines. These "thickets" create refuge for an assortment of young invertebrates including molluscs (chitons and scallops), echinoderms (urchins; (Kenner 1987) and brittle stars), and arthropods (crabs and barnacles) (Dearn 1987, pers. obs.).

Seasonal, temporal, and depth variability in morphology and physiology of $C$. tuberculosum populations was studied to provide insight on how these populations persist along the Monterey Peninsula. Overall, the data suggest that populations from $3 \mathrm{~m}$ and $10 \mathrm{~m}$ at both sites differ in morphological aspects (number of branch tips and biomass $\mathrm{m}^{-2}$ ) and physiological aspects (seasonal changes in productivity, growth, and calcification). Shallow coralline populations experienced higher irriadiances throughout 
the day compared to deep populations. Given that both populations have similar physiological parameters $\left(\mathrm{P}_{\max }, \alpha, \mathrm{I}_{\mathrm{c}}\right.$, and $\left.\mathrm{I}_{\mathrm{k}}\right)$, it may be the availability of higher irradiances at shallower depths that allow shallow populations to be more productive (growth and reproduction). To explain the higher number of branch tips in shallow populations, it is most likely due to the greater amount of light available at shallower depths allowing photosynthetic rates to be saturated during more hours of the day, therefore providing more light energy for investment into branch tips. Similar results for $\mathrm{P}_{\max }, \alpha$, and calcification were found in sudtidal C. tuberculsom from southern California (Bulach 2012). In contrast, a study conducted with $C$. tuberculosum from a tidepool in British Colombia (Guenther 2011) showed productivity to be 7-fold higher, pigment concentrations were 10 fold higher, while, photosynthetic efficiency was 10 fold lower in those individuals compared to this study. Individuals in this study were much more efficient in converting light energy into chemical energy and this may be explain the detected low pigment concentrations relative to other studies.

The site to site extent of these shallow coralline populations is unknown but is likely greater in coverage in wave exposed habitats along the Monterey Peninsula. These coralline thickets could serve as a carbon sink due to the longevity of species. This study reports their contribution on a small scale along the Monterey Peninsula. In these wave exposed areas, corralines may be the highest calcium accreting organism present in kelp forest habitats and should be monitored to understand the effects of climate change. 


\section{REFERENCES}

Adey, W. H. \& Vassar, J. M. 1975. Colonization, succession, and growth rates of tropical crustose coralline algae (Rhodophyta, Cryptonemiales). Phycologia 14:55-69.I

Andrake, W. \& Johansen, H. W. 1980. Alizarin red dye as a marker for measuring growth in Corallina officinalis L. (Corallinaceae, Rhodophyta). J. Phycol. 16:620-622.

Arnon, D.I. 1949. Copper enzymes in isolated chloroplasts. Polyphenoloxidase in Beta vulgaris. Plant Physiol. 24: 1-15.

Baeck, S. 1993. Morphological variation of northern Baltic Fucus vesiculosus along the exposure gradient. Ann. Bot. Fenn. 30:275-283.

Beer, S., Larsson, C., Poryan, O., \& Axelsson, L. 2000. Photosynthetic rates of Ulva (Chlorophyta) measured by pulse amplitute modulated (PAM) fluorometry. Eur.J. Phycol. 39:65-74.

Bock, W. J. 1994. Concepts and methods in ecomorphology. J.Biosci. 19:403-413.

Bruno, J. F., \& Edmunds, P. J. 1997. Clonal variation for phenotypic plasticity in the coral Madracis mirabilis. Ecology 78: 2177-2190.

Bulach, B. Year. Characterizing the response of coralline algae to ocean acidication. Masters thesis. San Diego State Unviersity, San Diego, California, 53 pp.

Calvert, H. E. 1976. Cultured studies on some Florida species of Caluerpa: Morphological responses to reduced illumination. Brit. Phycol. J. 11:203-214.

Clark, R., Edwards, M. S., \& Foster, M. S. 2004. Effects of shade from multiple kelp canopies on an understory algal assemblage. Mar. Ecol. Prog. Ser. 267:107-119.

Colombo, P. M. \& Orsenigo, M. 1977. Sea depth effects on the algal photosynthetic apparatus II. An electron microscopic study of the photosnythetic apparatus of Halimeda tuna (Chlorophyta, Siphonales) at $0.5 \mathrm{~m}$ and $6.0 \mathrm{~m}$ sea depths. Phycologia 16:9-17. 
Colombo-Pallota, M. F., Garcia-Mendoza, E., \& Ladah, L. B. 2006. Photosynthetic performance, light absorption, and pigment composition of Macrocystis pyrifera (Laminariales, Pheophyceae) blades from different depths. J. Phycol. 42:1225-1234.

Cowen, R. K., Agegian, C. R., \& Foster, M. S. 1982. The maintenance of community structure in a central California giant kelp forest. J. Exp. Mar. Biol. Ecol. 64:189-201.

Dayton, P. K., Currie, V., Gerrodette, T., Keller, B., Rosenthal, R., \& Ven Tresca, D. 1984. Patch dynamics and stability of some California kelp communities. Ecol. Monogr. 54:253-289.

Dayton, P., \& Tegner, M. J. 1984. Catastrophic storms, El Niño, and patch stability in a Southern California kelp community. Science 224:283-285.

Dearn, S.L. 1987. The fauna of subtidal articulated coralline mats: composition, dynamics, and effects of spatial heterogeneity. Masters thesis. California State University, Stanislaus, Turlock, California. 88 pp.

Devinny, J. S. \& Kirkwood, P. D. 1974. Algae associated with kelp beds of the Monterey Peninsula, California. Bot. Mar. 17:100-106.

Dring, M. J. 1990. Light harvesting and pigment composition in marine phytoplankton and macro algae. In P. J. Herring, A. K. Campbell, M. Whitfield \& L. Maddock (eds), Light and Life in the Sea (pp. 89-103) Cambridge, Cambridge Universtiy Press.

Ebeling, A. W., Laur, D. R. \& Rowley, R. J. 1985. Severe storm distubances and reversal of community structure in a southern California kelp forest. Mar. Biol. 84:287294.

Edwards, M. S. 1998. Effects of long-term canopy exclusion on the abundance of the annual alga Desmarestia ligulata (Light F). J. Exp. Mar. Biol. Ecol. 228:309-326. 
Edwards, M. S. \& Kim, K. W. 2010. Diurnal variation in relative photosynthetic performance in the giant kelp Macrocystis pyrifera (Phaeophyceae, Laminariales) at different depths as estimated using PAM fluorometry. Aquat. Bot. 92:119-128.

Estes, J. A., Danner, E. M., Doak, D. F., Konar, B., Springer, A. M., Steinberg, P. D., Tinker, M. T., \& Williams, T. M. 2004. Complex trophic interactions in kelp forest ecosystems. Bull. Mar. Sci. 74:621-638.

Fairhead, V. A. \& Cheshire, A. C. 2004. Seasonal and depth related variation in the photosynthesis-irradiance response of Eklonia radiata (Phaeophyta, Laminariales) at West Isand, South Australia. Mar. Biol. 145:415-426.

Foster, M. S. 1975a. Algal succesion in a Macrocystis pyrifera forest. Mar. Biol. 32:313-329.

Foster, M. S. 1975b. Regulation of algal community development in a Macrocystis pyrifera forest. Mar. Biol. 32:331-342.

Foster, A. B. 1979. Phenotypic plasticity in the reef corals Montastraea annularis and Siderastrea siderea. J. Exp. Mar. Biol. Ecol. 39: 25-54.

Foster, M. S. , \& Schiel, D.R. 1985. The ecology of giant kelp forests in California: A community profile. US Fish and Wildlife Service Biological Report 85(7.2): 152 pp.

Gabrielson, P. W., Miller, K. A., \& Martone, P. T. 2011. Morphometric and molecular analyses confirm two distinct species of Calliarthron (Corallinales, Rhodophyta), a genus endemic to the northeast Pacific. Phycologia 50:298-316.

Graham, M. H. 1997. Factors determining the upper limit of the giant kelp, Macrocystis pyrifera Agardh, along the Monterey Peninsula, central Caifornia, USA. J. Exp. Mar. Biol. Ecol. 218:127-149. 
Graham, M. H., Harrold, C., Lisin, S., Light, K., Watanabe, J. M., \& Foster, M. S. 1997. Population dynamics of giant kelp Macrocystis pyrifera along a wave exposure gradient. Mar. Ecol. Prog. Ser. 148:269-279.

Graham, M. H. 2004. Effects of Local Deforestation on the Diversity and Structure of Southern California Giant Kelp Forest Food Webs. Ecosystems. 7:341-357.

Guenther, R. 2011. Physiological Response of two species of articulated coralline algae during a simulated tidal cycle. Master thesis. University of Bristh Colombia, Vancouver, British Columbia, 88 pp.

Harrold, C., Watanabe, J.M., \& Lisin, S. 1988. Spatial variation in the structure of kelp forest communities along a wave exposure gradient. Mar. Ecol. 9:131-156.

Hay, M. E. 1986. Functional geometry of seaweeds: ecological consequences of thallus layering and shape in contrasting light environments. In T. J. Givnish [Ed.], On the Economy of Plant Form and Function. Cambridge University Press, New York, New York, USA. pages 635-666

Helmuth, B. S. T., Sebens, K. P., \& Daniel, T. L. 1997. Morphological variation in coral aggregation: branch spacing and mass flux to coral tissues. J. Exp. Mar. Biol. Ecol. 209:233-259.

Hurd, C. L., Harrison, P. J., \& Druehl, L. D. 1996. Effect of seawater velocity on inorganic nitrogen uptake by morphologically distinct forms of Macrocystis integrifolia from wave-sheltered and exposed sites. Mar. Biol. 126:205-214.

Hurd, C. L. 2000. Water motion, macroalgal physiology, and production. J. Phycol. 36:453-472.

Johansen, H. M. \& Austin, L. F. 1970. Growth rates in the articulated coralline Calliarthron (Rhodophyta). Can. J. Bot. 48:125-132.

Johansson, G. \& Snoeijs, P. 2002. Macroagal photosynthetic responses to light in relation to thallus morphology and depth zonation. Mar. Ecol. Prog. Ser. 244:63-72. 
Kenner, M.C. 1987. Population ecology of Stronglocentrotus purpuratus inhabiting sublittoral coralline mats within the range of the sea otter in California. Masters thesis. California State University, Hayward. Hayward, California. 64 pp.

Koehl, M. A. R., \& Alberte, R. S. 2008. Flow, flapping, and photosynthesis of Nereocystis luetkeana: a functional comparison of undulate and flat blade morphologies. Marine Biology. 99:435-444.

Kirk, J. T. O. 2011. Light and Photosynthesis in Aquatic Ecosytems. Third edition. Cambridge University Press, Cambridge, Massachusettes. 649 pp.

Littler, M. M. \& Litter, D. S. 1980. The evolution of thallus form and survival strategies in benthic marine macroalge: Field and laboratory tests of a functional form model. Am. Nat. 16:25-44.

Littler, M.M. 1980. Morphological form and photosynthetic performances of marine macroalgae: tests of a functional / form hypothesis. Botanica Marina. 22:161-165.

Lobban, C. S., \& Harrison, P. J. 1997. Seaweed Ecology and Physiology. Cambridge University Press, Cambridge, Massachusettes, 366 pp.

Lopez-Figueroa F. 1992. Diurnal variation in pigment content in Porphyra laciniata and Chondrus crispus and its relation to the diurnal changes of underwater light quality and quantity. Mar. Ecol. 13:285-305.

Luder, U. H., Knoetzel, J., \& Wiencke C. 2001. Acclimation of photosynthesis and pigments to seasonally changing light conditionsin the endemic Antartic red macroalga Palmaria decipiens. Polar Biol. 24:598-603

Mann, K. H. 1973. Seaweeds: Their productivity and strategy fro growth. Science 182:975-981. 
Mariani Colombo, P., Orsenigo, M., Solazzi, A., \&Tolomiom C. 1976. Sea depth effects on the algal photosynthetic apparatus. IV. Observations on the photosynthetic apparatus of Halimeda tuna (Siphonales) at sea depths between 7 and 16 m. Mem. Biol. Mar. Ocean. 6:197-208.

Martin, S., Castets, M., \& Clavier, J. 2006. Primary productivity, respiration, and calcificationof the temperate free-living coralline alga Lithothamnion coralioides. Aq. Bot. 85:121-128

Martone, P. T. 2006. Size, strength, and allometry of joints in the articulated coralline Calliarthron. J. Exper. Biol. 209:1678-1689.

Martone, P. T. 2010. Quantifying growth and calcium carbonate deposition of Calliarthron cheilosporioides (Corallines, Rhodophyta) in the field using a persitent vital stain. J. Phycol.46:13-17.

Monro, K. \& Poore, A. G. B. 2005. Light quantity and quality induce shade-avoiding plasticity in a marine macroalga. J. Evol. Biol. 18:426-435.

Neushul, M. 1971. Submarine illumination in Macrocystis beds. Nova Hedwig 32:241254.

Pearse, J. S. \& Hines, A. H. 1979. Expansion of a central California kelp forest following the mass mortality of sea urchins. Mar. Biol. 51:83-91.

Ramus, J., Beale, J. I., \& Mauzerall, D. 1976. Correaltion changes in pigment content with photosynthetic capacity of seaweeds as a function of depth. Mar. Biol. 37:231-238.

Reed, D. C. \& Foster, M.S. 1984. The effects of canopy shadings on algal recruitment and growth in a giant kelp forest. Ecology 65:937-948.

Reed, D. C. \& Schiel D. R. 1985. The ecology of giant kelp forests in California: A community profile. Biological report 85(7.2). Fish and Wildlife Service. $152 \mathrm{pp}$. 
Roberts, C. 1996. Light and plant orientation effects on pigment and reproductive patterns in Bosiella sp. Masters thesis. San Jose State University, San Jose, California, 51 pp. Paper 1290.

Schiel, D. R., \& Foster, M. S. 1986. The structure of subtidal algal stands in temperate waters. Oceanogr. Mar. Biol. Ann. Rev. 24:265-307.

Sebens, K. P., Witting, J., \& Helmuth B. 1997. Effects of water flow and branch spacing on particle capture by the reef coral Madracis mirabilis (Duchassaing and Michelotti). J. Exp. Mar. Biol. Ecol. 211:1-28.

Silva, J., Santos, R., Serôdio J., \& Melo R. A. 1998. Light response curves for Gelidium sesquipedale from different depths, determined by two methods: $\mathrm{O} 2$ evolution and chlorophyll fluorescence. J. App. Phycol. 10:295-301.

Steneck, R. S. \& Adey, W. H. 1976. The role of environment in control of morphology in Lithophyllum congestum, a Caribbean algal ridge builder. Bot. Mar. 19:197-215.

Steneck, R. S. 1986. The ecology of coralline algal crusts: convergent patterns and adaptive strategies. Ann. Rev. Ecol. Sys. 17:273-303.

Steneck, R. S., Graham, M. H., Bourque, B. J., Corbett, D., Erlanson, J. M., Estes, J. A., \& Tegner, M.J. 2002. Kelp forest ecosystems: biodiversity, stability, resilience and future. Environ. Conserv. 29:436-459.

Stengel, D. B., \& Dring, M. J. 1997. Morphology and in situ growth rates of plants of Ascophyllum nodosum (Pheaophyta) from different shore levels and responses to plants to vertical transplantation. Eur. J. Phycol. 32:193-202.

Vadas, R. L., Beal, B. F., Wright, W. A., Nickl, S., \& Emerson, S. 2004. Growth and productivity of sublittoral fringe kelps (Laminaria longicruris) Bach. Pyl. in Cobcook Bay, Maine. Northeastern Nat.11:143-162.

Watanabe, J. M., Phillips, R. E., Allen, N. H., \& Anderson, W. 1992. Physiological response of the stipitate understory kelp, Pterygophora califonica (Ruprecht), to shading by the giant kelp, Macrocystis pyrifera C. Agardh. J. Exp. Mar. Biol. Ecol. 159:237-252. 
Webb, W. L., Newton, M., \& Starr, D. 1974. Carbon dioxide exchange of Alnus rubra: a mathmatical model. Oecologia 17:281-291

Wernberg, T. \& Thomsen, M.S. 2005. The effect of wave exposure on the morphology of Ecklonia radiata. Aquat. Biol. 83:61-70.

Wheeler, W.N. 1988. Algal productivity and hydrodynamics- a synthesis. Progr. Phycol.Res. 6:23-58.

Wing, S. R., Leichter, J. J., Perrin, C., Rutger, S. M., Bowman, M. H., \& Cornelisen, C. D. 2007. Topographic shading and wave exposure influence morphology and ecophysiology of Ecklonia radiata (C. Agardh 1817) in Fiordland, New Zealand. Limnol. Oceangr. 52:1853-1864.

Yniguez, A. T., McManus J. W., \& Collado-Vides, L. 2010. Caputring the dynamics in benthic structures: environmental effects on morphology in the macroalgal genera Halimeda and Dictyota. Mar. Ecol. Prog. Ser. 411:17-32. 